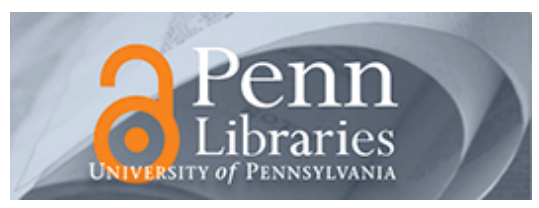

Studies in Visual Communication

Volume 9

Issue 1 Winter 1983

Article 7

1983

\title{
Vernacular Photography: FSA Images of Depression Leisure
}

George Abbott White

\section{Recommended Citation}

White, G. A. (1983). Vernacular Photography: FSA Images of Depression Leisure. 9 (1), 53-75. Retrieved from https://repository.upenn.edu/svc/vol9/iss1/7

This paper is posted at ScholarlyCommons. https://repository.upenn.edu/svc/vol9/iss1/7

For more information, please contact repository@pobox.upenn.edu. 


\section{Vernacular Photography: FSA Images of Depression Leisure}




\section{Vernacular Photography: FSA Images of Depression Leisure}

\section{George Abbott White}

Those deeply involved with the course of American history in the 1930s or the development of photography in general acknowledge the centrality of an immense body of work done by a handful of men and women: the Farm Security Administration photographs. While a spate of books (Rothstein 1978; Evans 1978; Meltzer 1978; Hurley 1978) has given us a much larger inventory of FSA photographs and, with Dorothea Lange and Russell Lee, the best inventory to date of biographical material about two of the FSA photographers themselves, it could be argued that quantity is no virtue. Indeed, in the case of these celebrated photographs, increasing the sheer number of them only compounds the problem.

Once again, two very familiar kinds of FSA photographs have been roused from their Library of Congress file drawers. For what purpose? To reinforce, in their condemnatory/celebratory "good pic" testimonial way, the image of the period and its people they already imprinted upon us the first (or was it the fifth?) time around. Absent then, as now, is a thoroughgoing examination of what FSA photographic work during those twelve mid- and post-Depression years was all about, what those nearly quarter million images may be said to have meant, if anything at all.

That examination cannot take place here, though the making of three assertions might perhaps begin it.

First, what have become the "classic" FSA photographs of the 1930s, rather than containing in themselves - by way of raw information or more processed allusions and implications - anything like a comprehensive definition of that time and its people, as we have been taught to believe, are complex articulations of a dominant ideology that actually discouraged a comprehensive, structural definition. What needs explanation, however, is the way in which they unconsciously fulfilled two ideologically acceptable modes of visual representation, namely, superficial condemnation and superficial celebration.

Second, the process by which the classic photographs were made and then came to achieve their wide recognition and their wide acceptance in itself constitutes an important element of the ideology. Both aesthetic and political dimensions of this process require examination in order to force awareness of the large number - the bulk - of FSA photographs that were made in other ways and did not achieve classic status.

George Abbott White is a teacher and a clinical child psychologist practicing in the Boston area. He is also Keeper of the Matthiessen Room, Harvard University.
Third, it is just those "vernacular pictures," organized around plain, seemingly mundane themes such as primary care medicine or games and sports, that may well provide us with a far more inclusive, fully adequate visual experience of the period, precisely because they break with the dominant ideology instead of reinforcing it. FSA photographer John Collier suggested as much when he said, in retrospect:

The pictures that we find to be the most important are going to be the ones that people think of as dull. It is the pedestrian shape of the file that holds the great cultural vision. The dramatic pictures will never finally be the thing that will tell us what was going on. [Quoted in O'Neal 1976:293]

Yet for reasons Collier did not or could not name, until now only the "dramatic" photographs have been read in careful, thoughtful ways. To understand the reasons for misreadings - to then place pictures of games and sports, for example, within a different ideological framework, thereby reading them in new as well as old ways - may convince us that the FSA photographers knew far more than they, or we, ever suspected.

\section{Who Pays the Piper, Etc.}

In a 1937 budget memo, the director of photography in the Roosevelt Resettlement Administration (the particular agency in the Department of Agriculture soon to become the Farm Security Administration, or FSA), one Roy Emerson Stryker, wrote the following justification for his project: "The sole purpose behind [the photographers' work] ... has been a simple and unspectacular attempt to give information," (Roy Stryker Collection, University of Louisville Photographic archive). Some four decades later, speaking to a packed Boston University auditorium and asked what he believed his FSA photographs were for, Russell Lee replied, without hesitation, "The country was in terrible shape. The people in Washington just didn't know what it looked like...." And, responding to a similar line of inquiry, artist Ben Shahn, who had made photographs for the RA/FSA from 1935 to 1938, observed,

We tried to present the ordinary in an extraordinary manner. But that's a paradox, because the only thing extraordinary about it was that it was so ordinary. Nobody had ever done it before, deliberately. Now, it's just called documentary, which I suppose is all right. ... We just took pictures that cried out to be taken. [Quoted in Pratt 1975:x] 


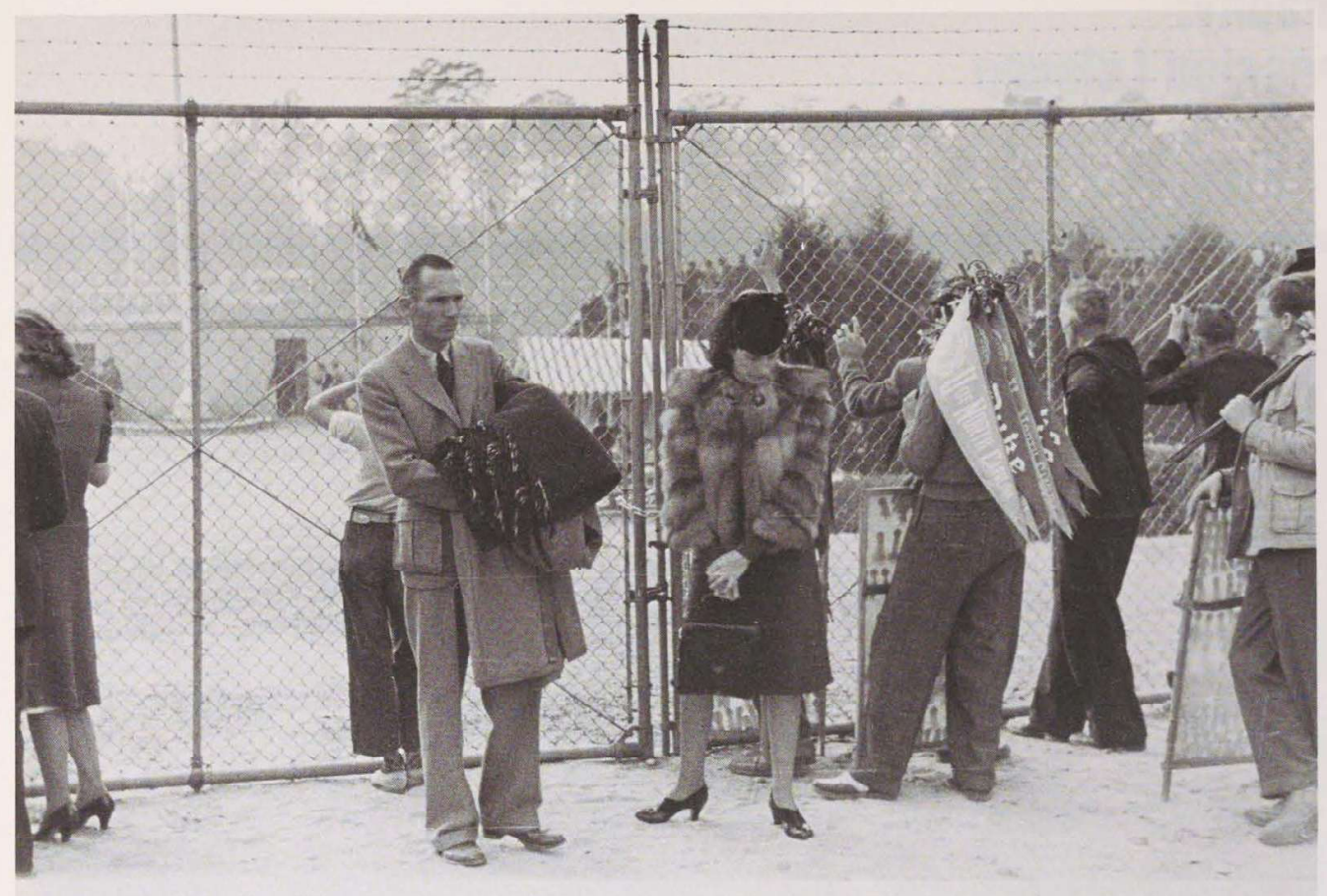

4 Figure 1 Marion Post

Wolcott. "Duke University, Durham, N.C. November 1939. Spectators outside the gate during a football game." 306860 M5.

Figure 2 Marion Post Wolcott. "Belle Glade, Florida. February 1941 Migratory workers playing checkers in front of a 'juke joint' during a slack season." 57105-D.
Shahn is close to key insights about the process and about the nature of vernacular pictures - their dumb or inarticulate ordinariness - but at this moment we must raise another question: whether in fact it was the pictures that did the crying out. That is, tucked into all three candid statements is the assumption that certain conditions of American life were not known to middle-class photographers and their (essentially) middle-class audience, to departments and agencies of the federal bureaucracy, to the centers of power, to "Washington." Moreover, there is an even greater assumption as to what would happen: that the conditions would suddenly, through the powerful enabling medium of photography, become conscious to the American public, and that mysteriously, though subsequently, this mass arousal would translate to political action that would, in turn, result in appropriate social remedies.?

But let us assume that the situation was entirely other. ${ }^{3}$ That America's economic and social inequities wrought, in the 1930s in particular, terrible physical and psychological injury throughout the land was very well known - if not in specific detail, certainly grossly, as public "statistics." Let us assume that one quite variegated group at the highest levels of national power continued to find themselves agreed upon the proposition that it was possible to justify the existence of those inequities, whereas another, similar group, agreed upon the necessity of denouncing the results of those inequities. In effect, the first group would be blind to what the second group would see.
The New Dealers, of course, were the ones who saw. They gained federal power by announcing a vision and they defended their power by legitimizing an entirely new way of seeing, no small thanks to agencies like the FSA, whose photographers they employed and whose pictures they widely distributed. The institutional function of those FSA photographers was thus always clear, if at times seemingly in contradiction with public policy. And this contradiction was the case because the structural intents of the New Deal were decidedly not clear, at least not to more than a few in the 1930s.

It is now a commonplace of economic history that the New Deal was not a wholesale restructuring of the American economy, but an easing of certain social dislocations caused by structural changes already well in motion. Like the situation of Enclosure in England prior to the Industrial Revolution, people had to be moved off the land to emerging urban centers of manufacture. They had to understand that it was cities where they would live and work, that return to their villages and their farms was impossible because it had slowly become impractical. Where English social policy - seen two centuries later-destroyed the small farm and satisfied national needs through huge imports, American social policy of the 1930s had the effect of marginalizing the small farm by favoring, in national crisis, mechanization and the creation of vast farms which, in addition to great quantities of foodfar more than could be immediately consumed-also produced enormous surpluses: an organic capital.

At this distance we can see that government agencies implementing the Agricultural Adjustment Act (AAA) provided direct loans as well as a wide range of solid agricultural and social services to large and 


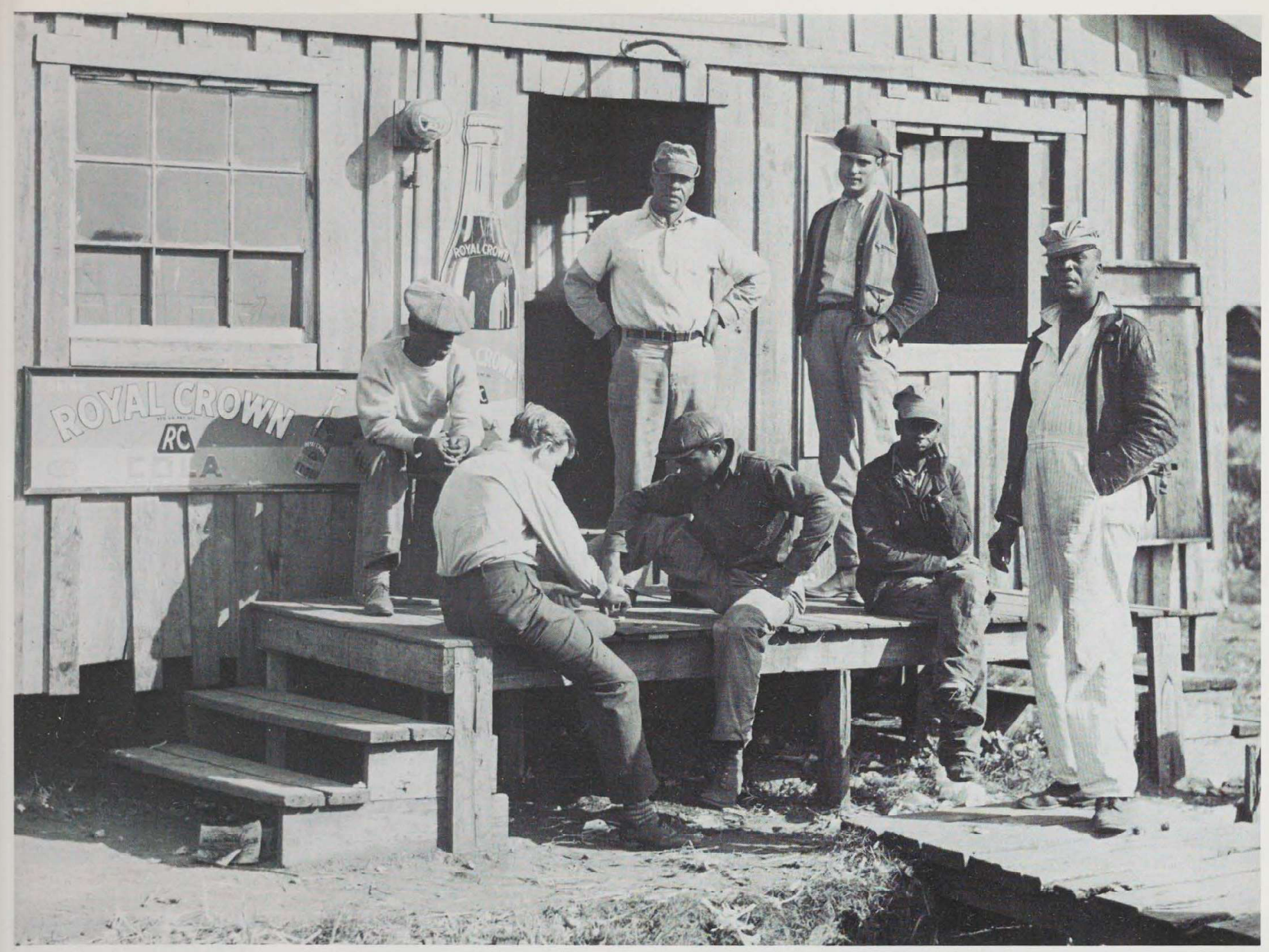

middle-income farmers to keep them, and their expertise, on the land. Although there was grumbling from less economically sophisticated quarters, support for this massive governmental intervention continued throughout the 1930s, and by the decade's end consolidation resulted in appropriately sprawling, industrially manageable tracts. Agri-business was an accomplished fact. Small farmers, however, were not overjoyed. Lacking much capital, lacking access by design to cost-saving finances, processing and transportation networks, they rapidly joined the tenant farmers who had once rented their land, the hands and part-time farm laborers whom they once had hired, in good years. Forced off the land, all took to the roads.

These were the Oakies, the Arkies, the black and white stream that would become, in Robert Coles's apt phrase, "the South goes North" (Coles 1972). And what was to be done with these millions? In no way could such numbers of the new dispossessed be severed from the social fabric and then allowed to go their way. Sullen and fearful, the were also dimly aware of causes, certainly local and to some extent regional ones. Their frustration and anger was poten- tial human dynamite whose explosion could easily provoke violent counter-explosions, in containment or in punishment. And then what? No doubt, went the reasoning, some of these people could be cooled out to urban occupations, as in England. Others, however, the really stubborn ones, would have to be supported as farmers, for a time.

The Resettlement Administration (RA), later the FSA, was given the task of picking up the pieces the $\mathrm{AAA}$ and parallel policies had created. Enter the Historical Section of the FSA, Stryker's FSA photographers, whose role was twofold. On the one hand, the condition of these dispossessed required dramatic presentation to the American public-hence the condemnatory mode of visual representation. Increased public awareness, properly organized (or orchestrated), validated a social policy that guaranteed the RA some funds to make loans to small farmers, to establish government-supervised camps for migrants (those "good" camps seen in John Steinbeck's novel The Grapes of Wrath) and in health care clinics at those camps. It was not enough recording the wornout land or even the horrendous living conditions of those forced off their farms, on the road (the palpable 
sons why men and women might actually be moved to revolt): the FSA cameras also had to demonstrate the other side-that FSA programs could work and, later in the 1930s, were working

This second role required cameras searching out an ineffable but absolutely essential quality, character: hence, the celebratory mode of visual representation, which suggested that underneath the rags and the grime was a backbone capable of re-establising a decent life. Given a helping hand, guided by experts, sheltered from the more aggressive economic forces, these dispossessed would make a go of it. And the public would thereby be reassured that they had once again settled back down into an unthreatening passivity.
The two kinds of classic photographs served an additional purpose, which had its not-too-farfetched parallel a decade later. Just as dramatic anticommunism, stirred up at the bottom but directed from the top, provided an ideological cover for launching the Marshall Plan and its successful penetration of post-World War II European markets, so dramatic images such as Lange's "Migrant Mother" (Nipomo, California: 1936), "Ditched, Stalled, and Stranded" (San Joaquin Valley, California; 1935), or Russell Lee's "Christmas Dinner in Tenant Farmer's Home" (Southeastern lowa; 1936), served on a smaller scale to engage and then to deflect public attention, keeping the fans watching the plays on the field while the real game was in the dugout.

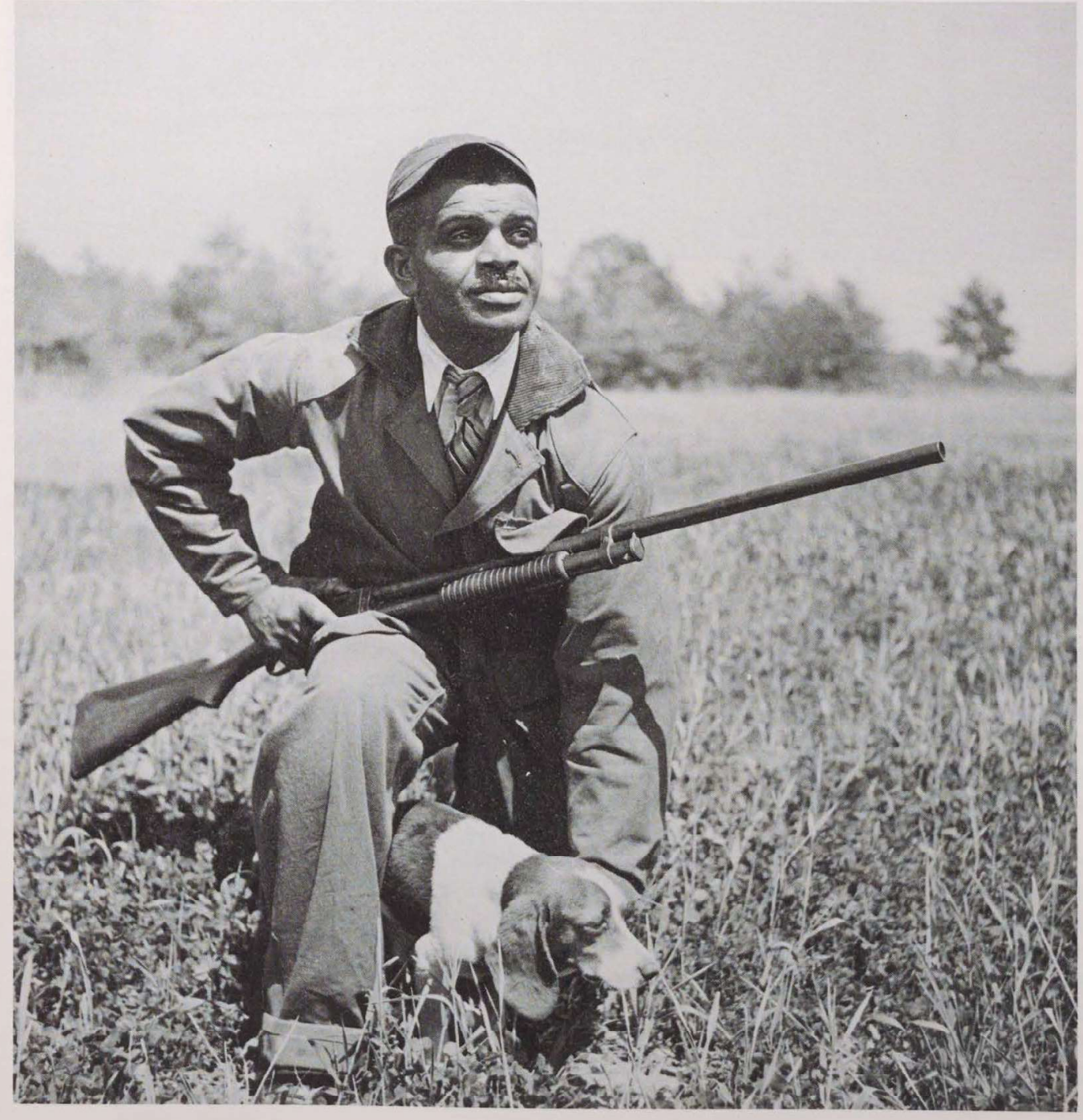

Figure 3 Pat Terry. "Newport News, Virginia. May 1940. Negro shipyard worker finds recreation in hunting." OWI 1923-E. 


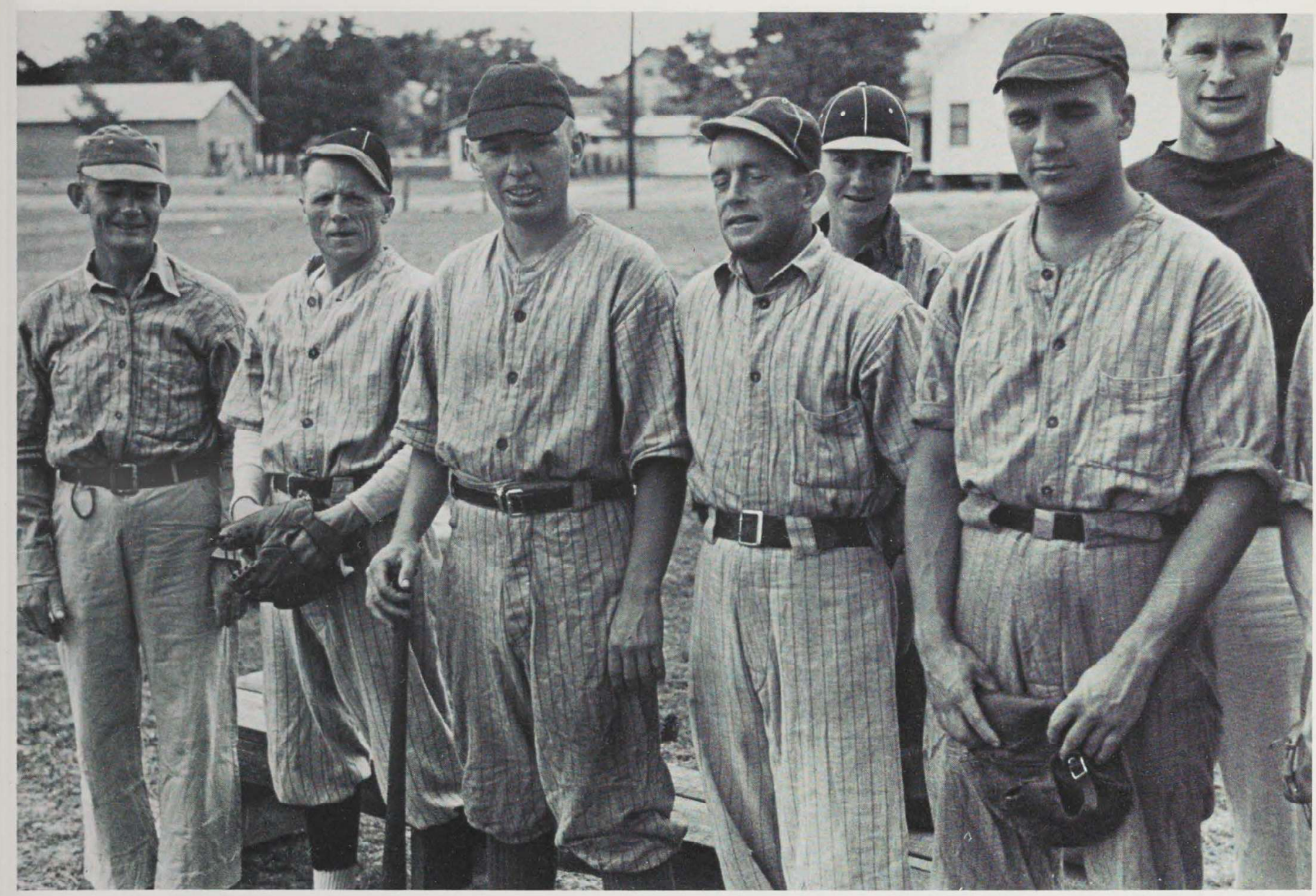

Figure 4 John Vachon. "Irwinville Farms,

Georgia. May 1938. A

U.S. resettlement administration project,

near Irwinville, Georgia. A baseball team." 1157-M2.
Figure 5 Ben Shahn.

"Crossville, Tennessee. 1937. Cumberland

Homesteads, a U.S. resettlement administration project. Dancers who have been taught by Leonard Kirk." 6267-M4.

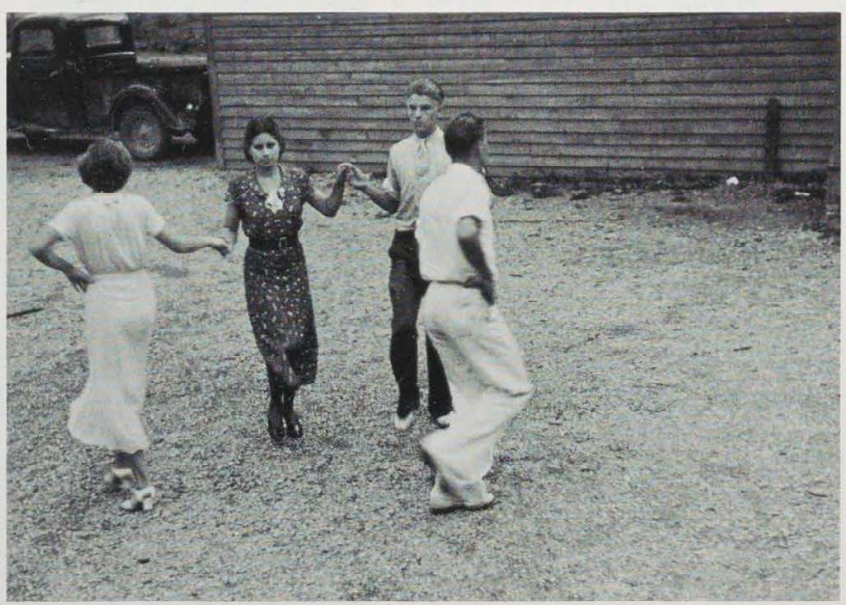




\section{The Beautiful Pictures}

Knowing the maker is nearly to know the process of making. More than most photographs of their time, more than many since, the FSA photographers were masters of the image-middle-class professionals who could deliver a particular image or group of images on demand.

This is not to imply that all were master technicians. Lange was, by all accounts, a notorious example of mechanical ineptitude; Evans openly scorned "technical tricks." Yet Lange also got exactly what she wanted, from skilled darkroom technicians to precisely the right image, as documentary filmmaker Pare Lorenz emphasized in his 1941 review of her pictures of the dispossessed:
She has selected them with an unerring eye. You do not find in her portrait gallery the bindle stiffs, the drifters, the tramps, the unfortunate aimless dregs of the country. Her people stand straight and look you in the eye. [Quoted in Meltzer 1978:105]

And in his directions for the photograph, "Winter Resorters, Florida" (1941-1942), Evans could reveal an astonishing ability to locate, and then to insist upon, the detail he wanted:

\section{NOTE FOR THE ENGRAVER:}

Please note unsightly light triangles, seven of them, above the numbers. Could you simply black them all out, matching the black next to them. Also: try to get clearly the veins in the left leg of the woman, but without retouching. Also: We want the lettering on the newspaper at right to be as clear as possible, again, without retouching.
Figure 6 Gordon Parks. "Daytona Beach, Florida. February 1943. BethuneCookman College. Physical education class." 17087-C.

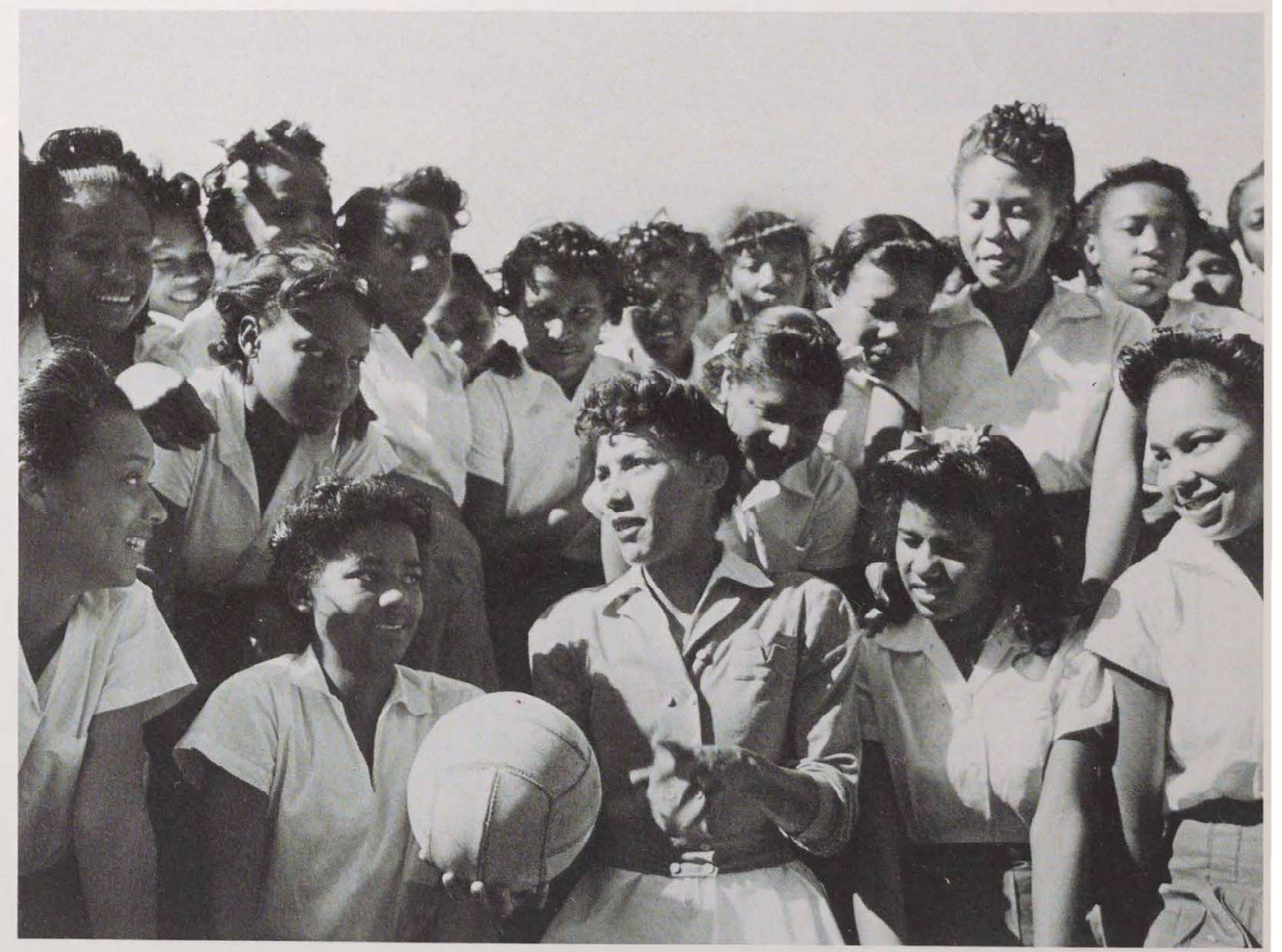




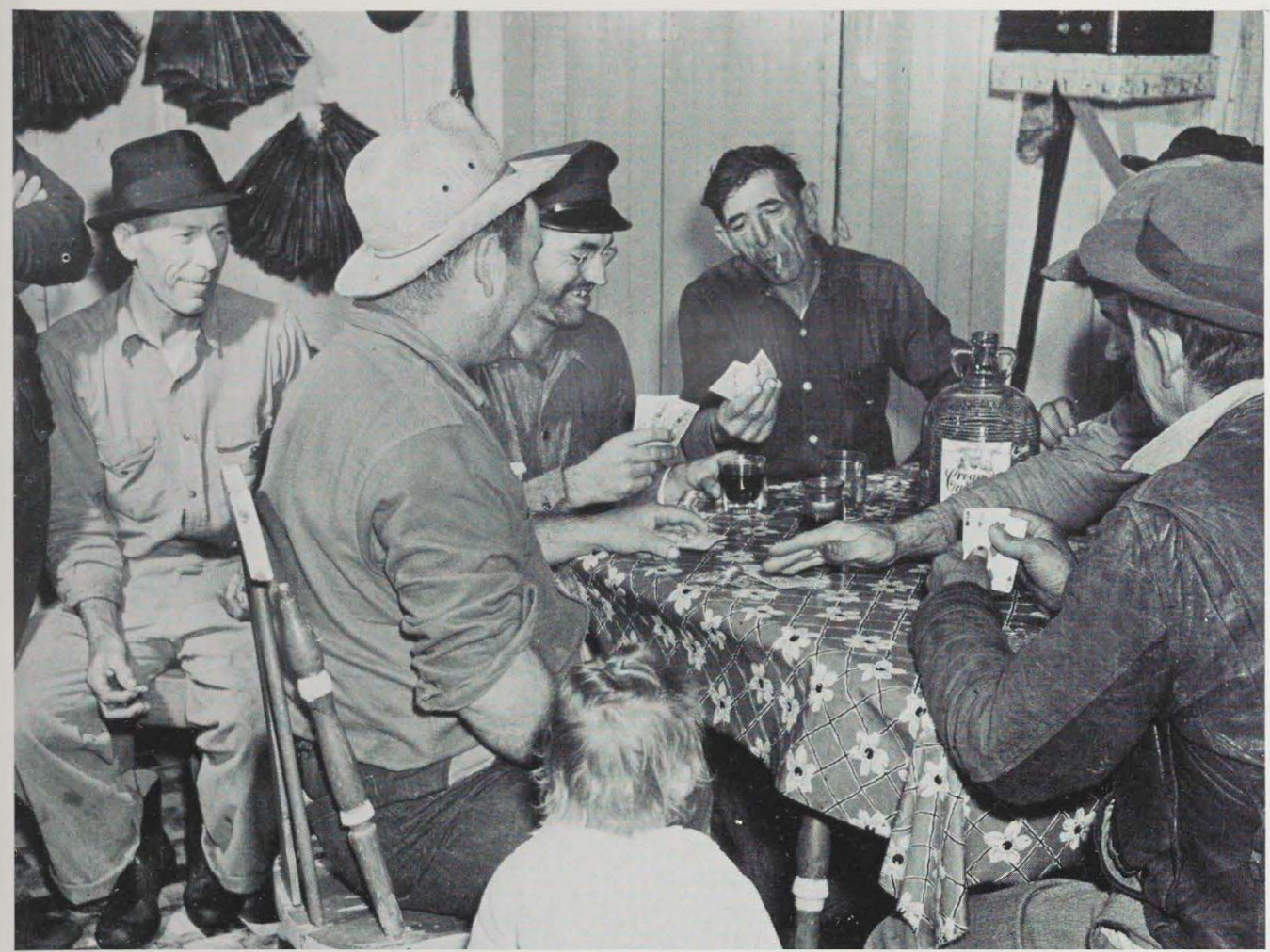

Figure 7 Marion Post

Wolcott. "Delacroix Island, St. Bernard Parish Louisiana. January 1941. Spanish muskrat trappers drinking wine and playing cache, a form of poker, in their camp in the marshes." 56850-D.

Yet even such demonstrable technical skill does not imply that all were aware of the ideological freight their work carried or the ideological uses to which their work would be put. But few of the FSA photographers would have agreed that their photographs were without freight and even after the passage of four decades would bridle at any evaluation of their work or its impact that regarded their photographs as mere conveyors of neutral information. Their flashy contemporary, outrageously exploitative Fortune photographer, Margaret Bourke-White, would dissemble, "With a camera, the shutter opens and closes and only the rays that come in to be registered come directly from the object in front." In marked contrast, FSA photographers repeatedly acknowledged the aggressive implications of their profession and were sensitive to the personal dislocations their intrusions could create. ${ }^{4}$ Moreover, for seven of the ten-Jack Delano, Carl Mydans, Marion Post Wolcott, John Collier, Evans, Lange, and Lee-there had been a formal association with the arts, and with the latter three experience including not only academic study and supervised making, but the commercial marketing of images to a discriminating clientele. ${ }^{5}$ Even someone at the furthest remove from this process, Gordon Parks, who was with the FSA marginally and briefly, was not immune to the ideological implications of the form. Parks had had an initially naive interest in pictures mainlined by the wife of Joe Louis, "who asked him [for what might be characterized as his tutoring in middle-class attention] to come to Chicago to photograph a new line of ladies' fashion."
Biographers of artists unfailingly recite the "sacrifices" their subjects have made in order to make art. Left unspoken is the fact that as a function of their class, these artists had a choice. Had they chosen not to do art, they had the tangible option of doing something else, and likely living quite well. FSA photographers were in a similar position, and, though novelist Eudora Welty was not one of them, what she wrote of the pictures she took while with a Works Projects Administration (WPA) agency, One Time, One Place (1971), illuminates these issues:

And had I no shame as a white person for what message might lie in my pictures of black persons? No, I was too busy imagining myself into their lives to be open to any generalities. [p. 6]

A question is implicit in what Welty calls her need to "imagine" herself "into their lives," one she anticipates and then goes on to answer with a candor equal to Agee's:

Perhaps I should openly admit here to an ironic fact. While I was very well equipped for taking these pictures, I was rather oddly equipped for doing it. I came from a stable, sheltered, relatively happy home that by the time of the Depression and the early death of my father . . had become comfortably enough off by small-town Southern standards. ... I was equipped with a good liberal arts education (in Mississippi, Wisconsin, and New York). .. . I was bright in my studies, and [yet] when ... I returned home from the Columbia Graduate School of Business ... of the ways of life in the world I knew absolutely nothing at all. [pp, 6-7] 


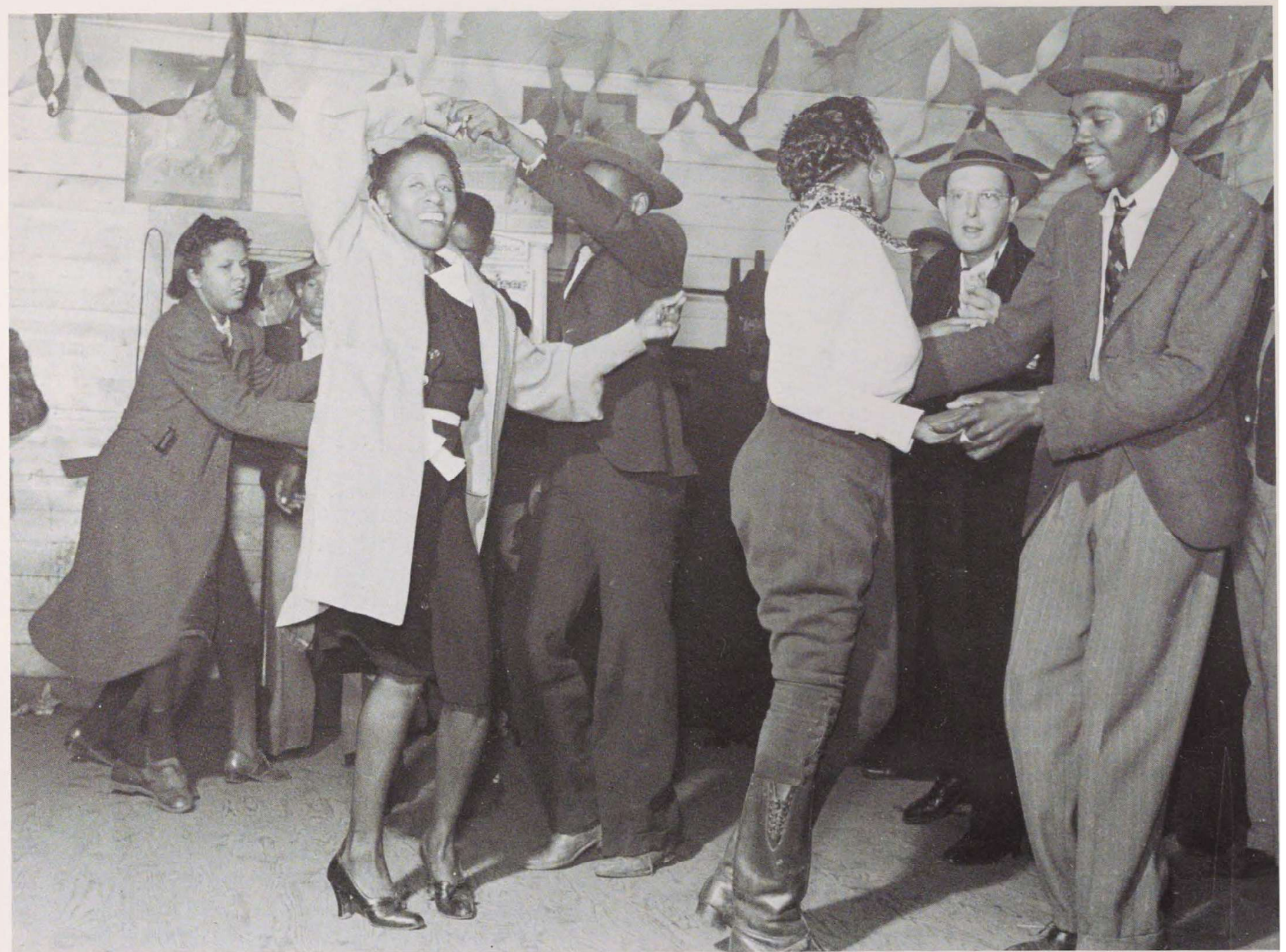

A "background" that allowed her to know the world in reality allowed her to know only a fraction of the world. Like the FSA photographers of her time, Eudora Welty realized that the real irony was that social privilege resulted in, ultimately, personal impoverishment. And like them, she realized that this imbalance could be corrected only by bringing one's work closer and closer to the "everydayness" of black and white working people's lives, as they, not she, experienced it.

In this sense, it is more than unfair to regard the FSA photographers as "dupes" of either left or right wings of the New Deal, irresponsibly "naive" of the implications of their work, or as passive "agents" of an aggrandizing federal bureaucracy. The true situation was and remains far more complex and far more knotty than easy labeling will allow. But Welty's brief account suggests why the FSA photographers were never entirely subservient to the ideological directives outlined earlier. True, their professional status put them in a sharply asymmetrical relationship in any en- counter, but their own unconscious needs ("I knew nothing at all') coupled with the needs of their work ("imagining ... into their lives") were so apparent that their subjects satisfied both by being able to insist upon an element intrinsic to any authentic relationship-the subject's need for attention. So the meaning of Shahn's insight, the phrase "extraordinary manner," becomes clearer: nothing less than the same quality and intensity of attention must be paid to an "invisible people" as they, in the course of things, pay to the very visible people the social structure automatically rewards.

The appeal of the FSA photographs becomes obvious. Experiences denied by the confines of class were now available to that class, and if there was something slightly titilating and exotic about "how the other half lives," there was also the solid, four-square element of necessity, since these photographs stimulated the feeling of incompleteness in the viewer that, in turn, compelled attention.

Unfortunately, experiencing worlds through photographs cuts two ways. Susan Sontag (1977:24) writes about photographs as cheap knowledge. She warns that "they make us feel that the world is more avail- 
4 Figure 8 Marion Post Wolcott. "Clarksdale, Mississippi. November 1939. Jitterbugging in a Negro juke joint on Saturday evening in the Delta area." FSA 52596-D.

Figure 9 Jack Delano. "Greene County, Georgia. October 1941. The White Plains bridge club." 46202-D.

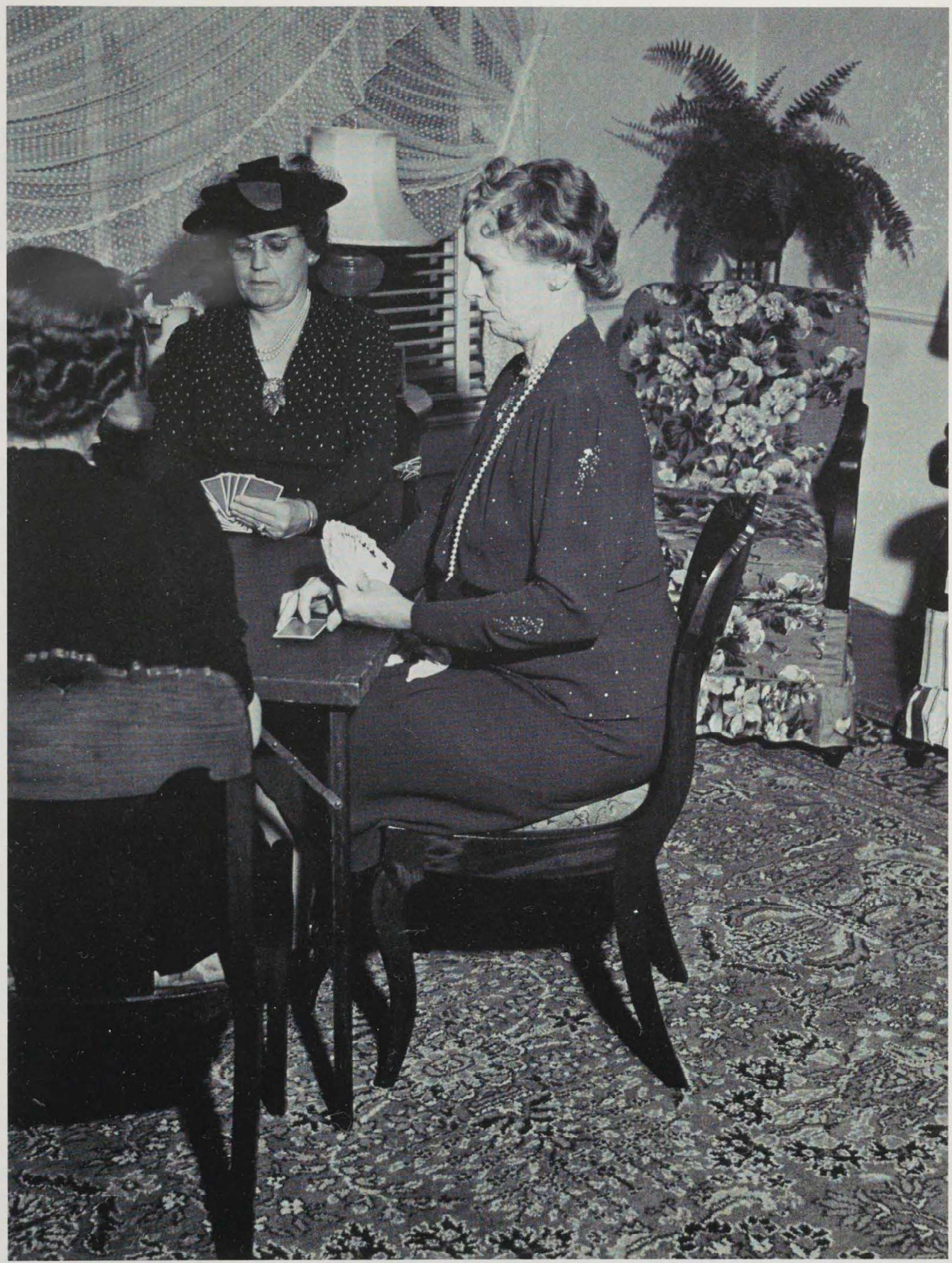




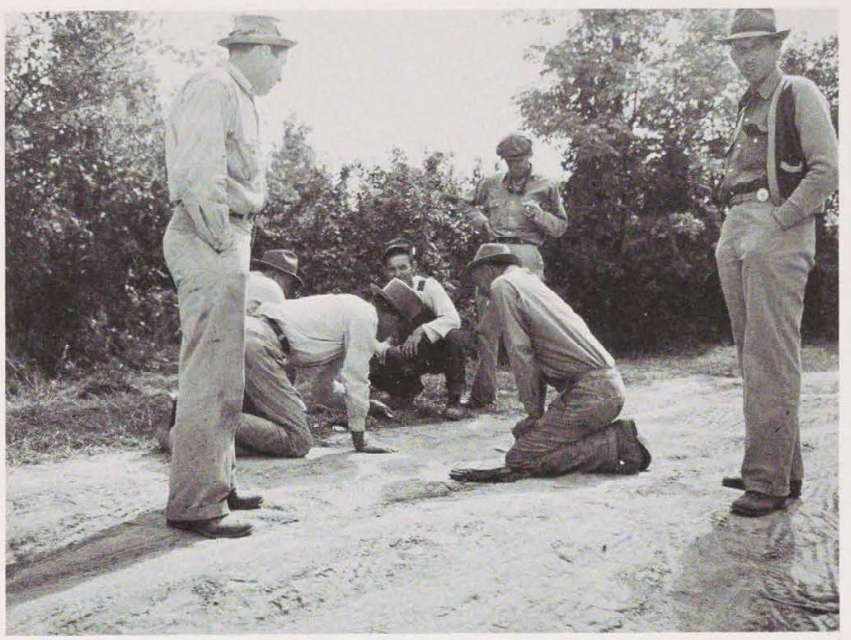

Figure 10 John Vachon. "Little Rock, Arkansas to MissouriArkansas state line. October 1942. War emergency pipeline from Longview, Texas, to Norris City, Illinois. Crap game during lunch hour." 9263-D.

able than it really is." This is never more the case than with the classic photographs, the "beautiful" ones, because these photographs are made in such a way that they fulfill the viewers' need to be reassured that the world hasn't gotten any worse. The viewers get all they want-the "feel" - which preempts, in crucial emotional and political ways, any further involvement. The experience these photographs occasion is not an absolute one, nor even a matter of a continuum. Elements of either the condemnatory or celebratory mode can be identified in them to some extent and people are, after all, moved by them. The experience is at its most obvious and most extreme, however, with a third kind of classic photograph—the artists' photograph. This third group, as exemplified by certain work by Evans, has been intensively appreciated by a narrow spectrum of photographic artists and art historians for their abstract, formal qualities. ${ }^{6}$ They encourage instant identification as kinds, and they insist upon concentrated, involved analyses of the most demanding drill.

Arthur Rothstein's variously titled ${ }^{7}$ photograph of the 1936 Dust Bowl in Oklahoma is a striking example of the first mode. Some versions have been printed as lighter or darker, sharper in focus, it seems, than others, but all show a barren landscape where motion reigns supreme, where human life, in a not-too-distant background (a man, a youth alongside, a small child not far behind), is bowed by wind, where even solid man-made structures (a low plains house) visibly demonstrate the abrasive, bleaching effects of this natural force. Obviously what is being condemned here is less an "act of God" and more a social structure (or lack of one) that allows human life to be at its mercy.
The celebratory mode is exemplified by Dorothea Lange's "Hoe Culture, Alabama, 1937," a straightforward photograph of someone holding a portion of a handle. While basic elements can be located in photographs of the landscape or of man-made structures, the human presence is central to this mode and, if not directly present, is usually implied: What is being celebrated here is not virgin landscape, but the organic relationship of necessity between man and nature and, more particularly, in this period of time, between Americans and their land. The celebratory photographs reinforce the pastoral myth and revive a waning expectation that productivity must result from this relationship, even as the nation becomes irrevocably urbanized and rural values are made inoperative-except as nostalgia-for lack of an appropriate arena.

Man prevails, the viewer is persuaded, though this is made possible only by that earlier mentioned indomitable spirit-hence, photographs in this mode are essentially character portraits and borrow heavily from studio techniques. ${ }^{8}$ So, in Lange's photograph, we do not need to see either the head and shoulders, or below the thighs, as direct, close view we are given will provide us with ample enough details from which to draw our conclusions. The weathered, sweat-stained handle is part weapon, part enemy, part old friend, and as such has complex familiarity; not exactly cradled, it is not held in a vise grip either. The angles of handle and holding hands, arms, the quality of focus around details of badly worn denim field jacket and patched denim pants, are concentrated without clutter, and the soft richness-rather than glaring sharpness - of contrast has the further effect of ennobling these honorably worn garments, these work-worn hands and muscled arms and, by implication, the entire enterprise beyond. To sacrifice, in Greek, is to make sacred; these celebratory photographs assure us the ancient metaphysic lives by assuring us that this labor has, in effect, sanctified the laborer, whatever the material outcome in a troubled period.

Virtually any of Evans's FSA photographs will do as an example of the third mode, though some, of course, are better made than others. The first thing one notices is the surface polish and a terrific sharpness of detail. For contrast, whites are very white and blacks, as we might recall from Evans's "Note For The Engraver," quoted earlier, are very black, and matched. These points might be dismissed as simply a function of technical production, but it is a produc- 
Figure 11 Marion Post

Wolcott. "Warrenton,

Virginia. May 1941. One of the judges at the horse races." 57465-E.

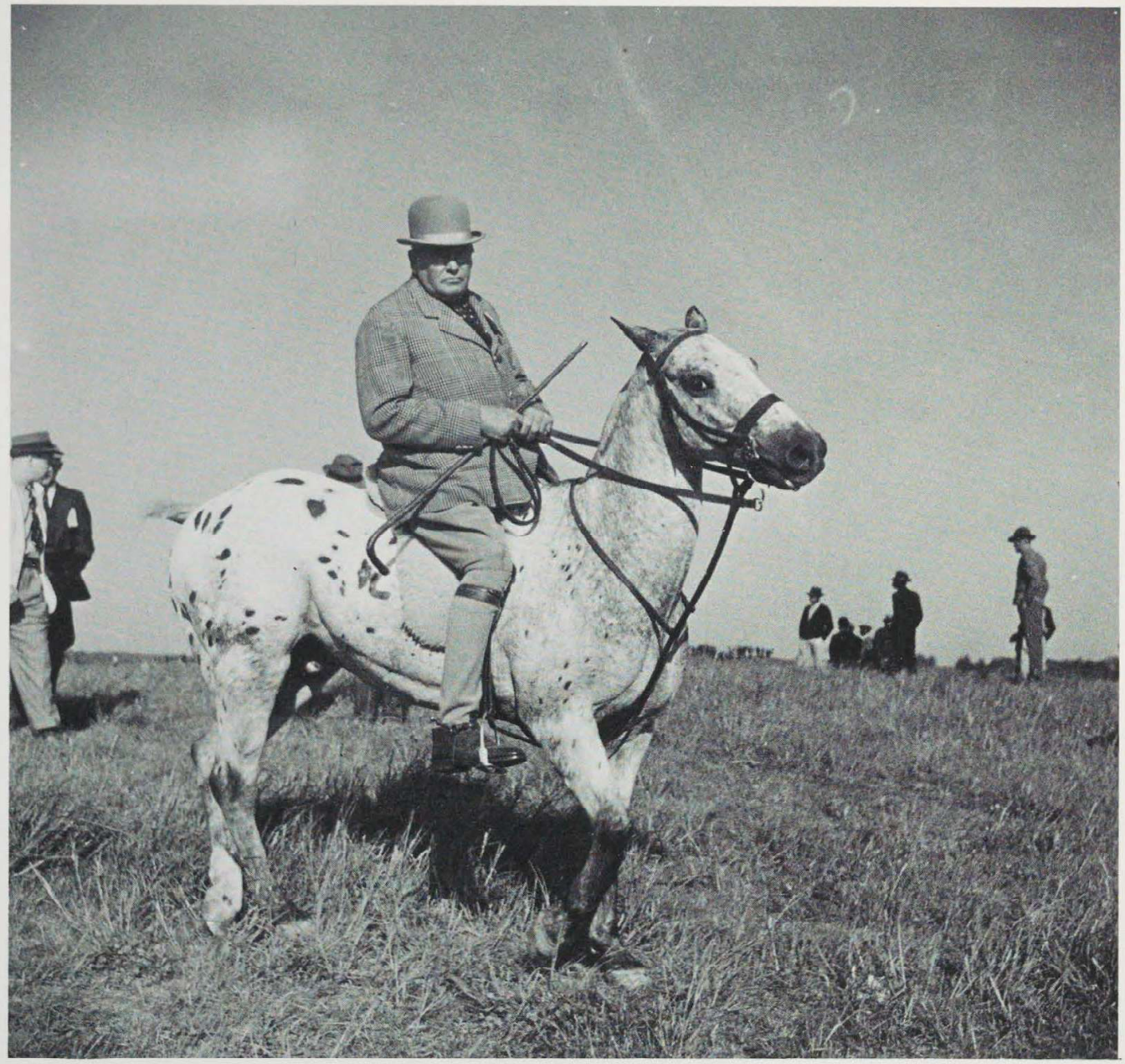

tion geared to following standards learned in producing portraits of important people or large industries, who each have a keen sense of what details they wish. It is also a production of detail and contrast geared not only for explicit aesthetic and personal standards, but also demanding reproductive needs; if these images are to be rapidly and widely distributed in the mass media, they must be made in a particular way. Then there are the classic elements of order, harmony, and balance, which in these photographs means that awkward angles, "irrelevant" or confusing details, unwanted objects or people, are cropped, spotted, or otherwise removed in the darkroom. Everything goes together, and the unity it approaches is a dramatic but nonreferential quality of overall composition. It is a shibboleth of classical aesthetics that "great art" sends us back into the world, perhaps not entirely refreshed, but usually fortified to meet what may lie before us. Yet quite the opposite may in fact be the case.
Evans's interiors of Hale County, Alabama, sharecropper's shacks or his haunting frontal views of rural churches are designed to beautifully freeze moments in time. Emotions are intensified-by careful positioning, enormous attention to the most minute detail, distinct, yet never too sharp a tone-such that something curious occurs. We don't so much see as experience the things of this world, and we do so in such a way that the experience comes to take the place of the things of this world; we prefer the photograph of that church interior in Alabama to actually sitting at the keyboard of that organ and pumping away at the foot pedals. ${ }^{9}$ 
Figure 12 Russell Lee.

"Crowley (vicinity),

Louisiana. November

1938. Joseph LaBlanc, a

wealthy Cajun farmer:

standing on the steps of his home with some birds from an early morning shoot." 11777-M2.

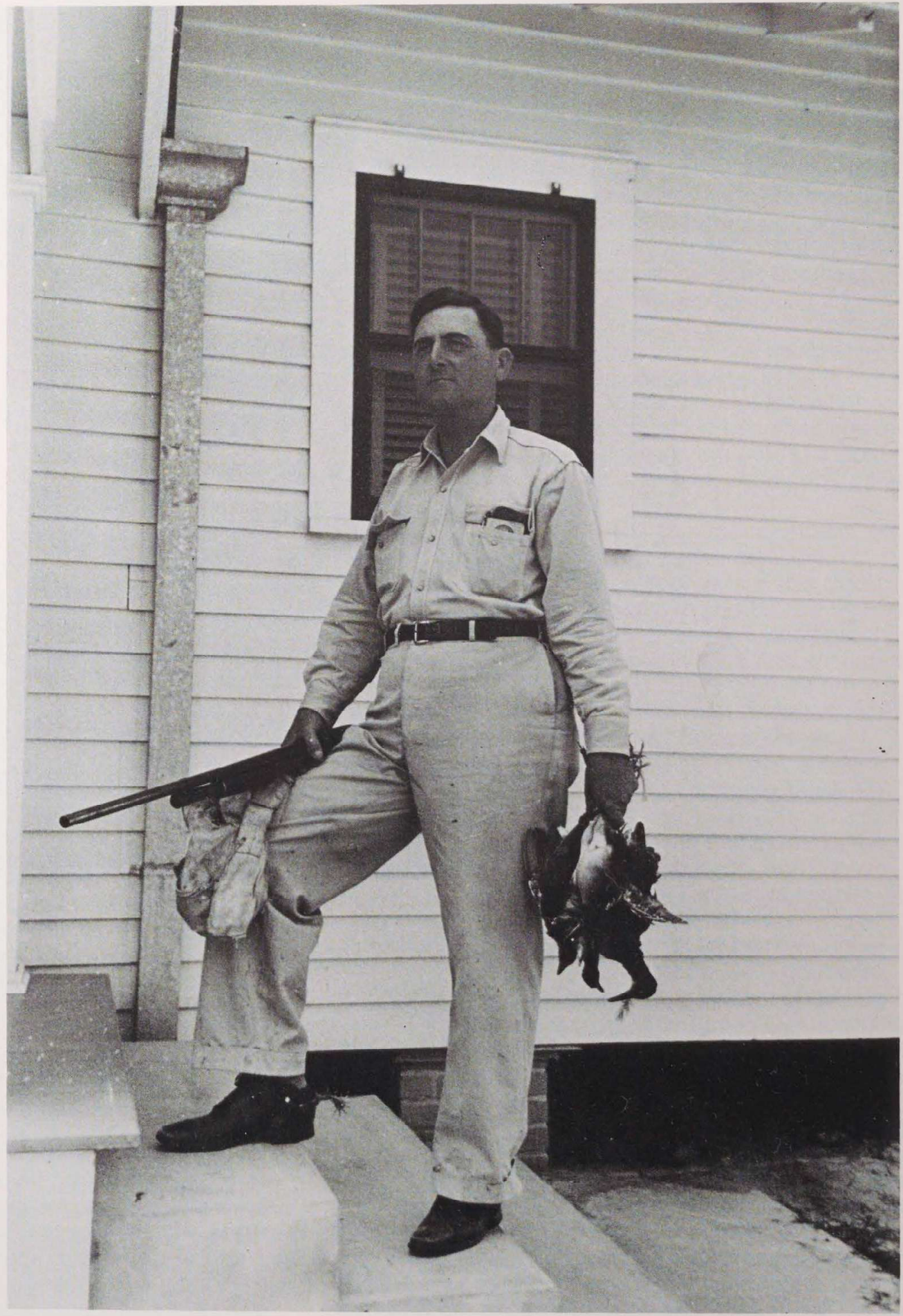




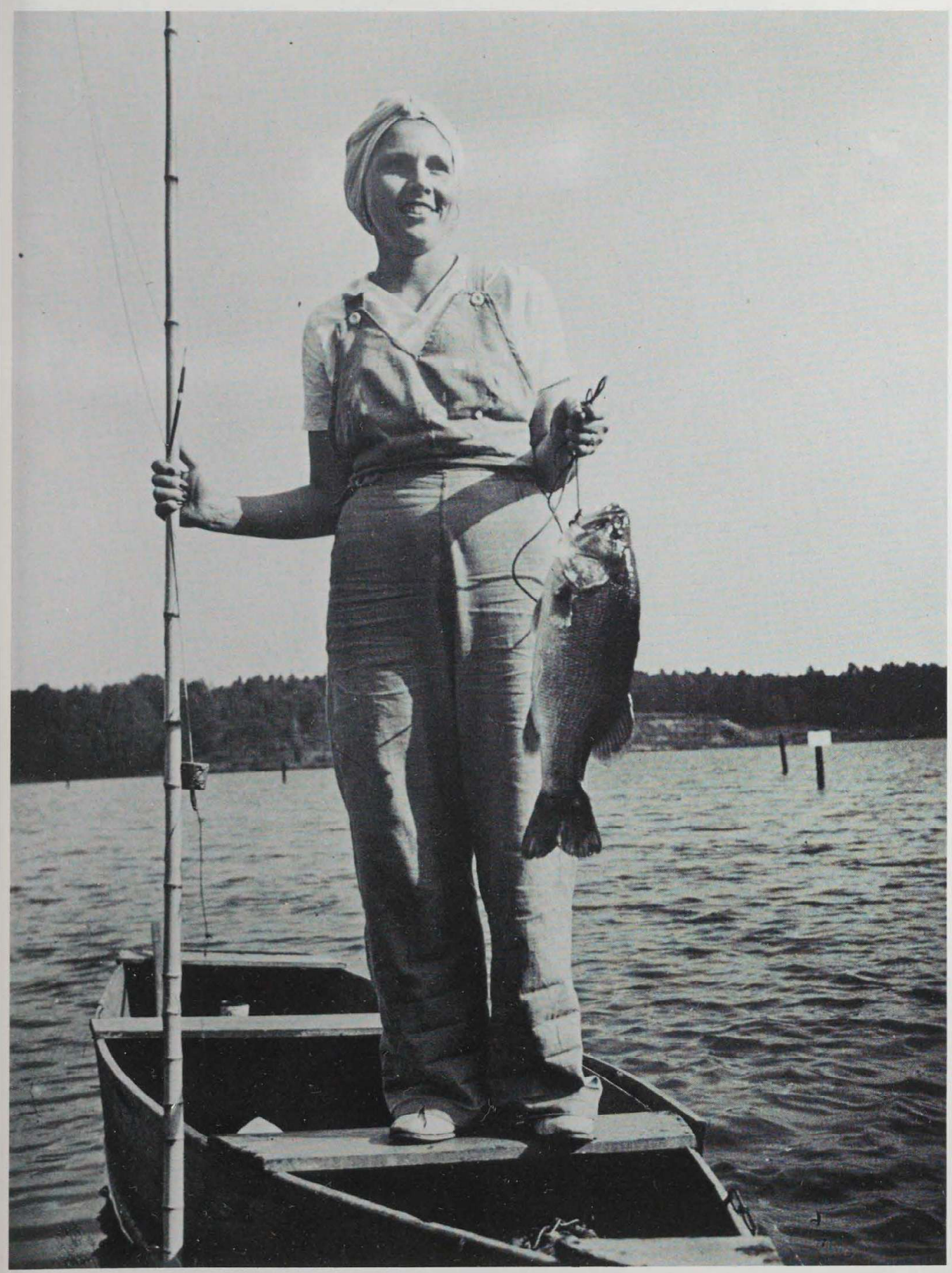

Figure 13 O. S. Welch. "Atlanta, Georgia. July 1942. Mrs. J. L. Tuggle, of 885 Gilbert street, with a nine-pound bass she caught, using catawba worm bait on a No. 10 hook. This was her first experience as a fisherman." R2-904. 


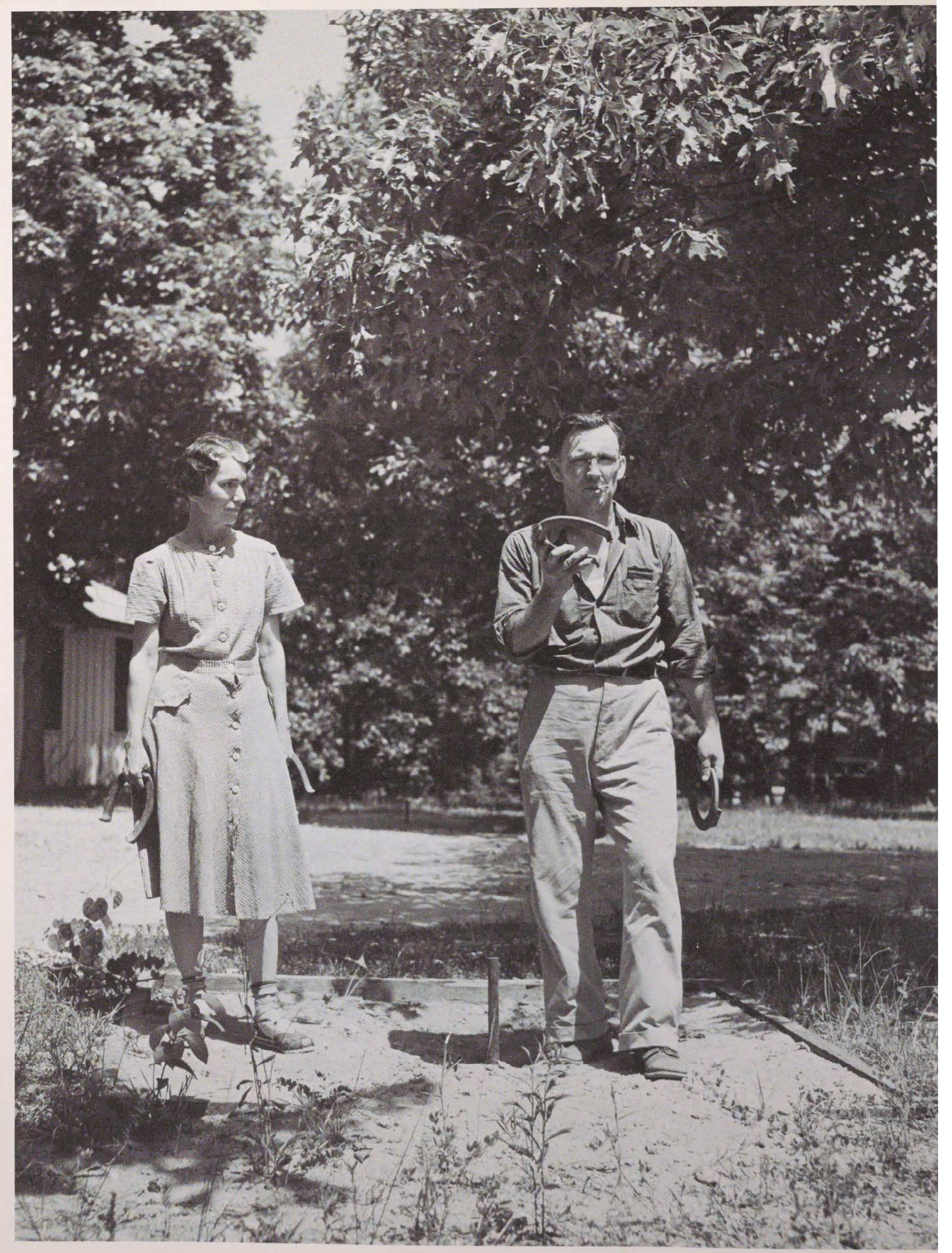


This would be all well and good if the experience would finally send us back into the world ready to do something after our moment of contemplation. It does not, and that moment can be a long one. The photographs' clarity humbles us, not to the discrete "I" who will act, but the "I" who, like the billions of other discrete grains of sand, simply is. The beautiful pictures are so complete in themselves that it is within thememotionally - that we remain, during and after the time we view them. (The intensity of our involvement is fueled by the contrast between the pedestrian subject matter-peeling road signs or neat shelves of seed packets in a general store, in an Evans photograph-and the extravagant attention the photographer has paid to that subject matter.) We are rapt before the icon image, engaged, then quite relaxed. The pressure is off, and should we return to the internal hum of the photograph repeatedly, gone is that other need - to understand the conditions that caused the peeling paint, or why the seeds sit unbought, why there is no money ... much less to commit ourselves to a struggle that would address and then hopefully change those conditions.

Figure 14 Arthur Rothstein. "Lauderdale County, Alabama. June 1942. Tennessee Valley Authority. Julien H. Case and his wife pitching horseshoes on their farm." 3946-D.

\section{Vernacular Pictures}

In contrast, vernacular pictures ${ }^{10}$ are never cool and formalized; the poverty in them is rarely beautiful, in Whitman's or anyone else's sense; and the viewer, conditioned by the three previously noted modes of visual representation, is hard put to know how to respond to these images of the ordinary, photographed in an "ordinary" fashion.

Unlike the classic photographs, they present a bland and often somewhat confusing exterior, which is not immediately engaging. And vernacular pictures are not easy to be "in," once the viewer has managed to define and then gain a point of entry. Having seen them once, the viewer does not usually return. Why? Because the "subject matter" seems easily exhausted and, as a consequence, there is no intellectual or affective need. Absent as well are the formal elements of classic photographs, which might pump up emotion, enhance memorability. Trained on stunning surfaces and well-defined images, the viewer wonders about the grayness of it all, is annoyed by the inarticulateness of a construction that seems to require, as part of its meaning as well as its information, very specific captions below or alongside the pictures, detailed, explanatory texts, maps, and diagrams. Can't these photographs stand alone, the viewer objects? What was it that engaged the photographer in the first place; wasn't the photographer as puzzled as the viewer that the "essence" of the subject didn't turn up in the developer, or at least under the enlarger?

The point is that vernacular pictures are by nature shy, necessarily offensive, even hostile and unrevealing to the photographer or viewer who is tied to an ideology that trivializes them into "sociological studies" or mindless popular culture "highs" almost reflexively. ${ }^{11}$ On some level, the FSA photographers must have understood this immense vulnerability. Reprinting a negative shortly before her death, a negative she had made while with the FSA in 1936, Dorothea Lange began to cry. "The print is not the object," she said aloud, turning to her darkroom assistant after she had composed herself, "the object is the emotion the print gives you" (Meltzer 1978:153). She had gotten close to people's lives. For an instant, she had remembered the meaning of those lives again, as they must have once flooded over her, decades ago, in the midst of the Great Depression.

This selection of pictures, "Games and Sports in the South," could have included other similar images, though not many. None are available prior to 1937 because, up until then, the FSA was searching out things to condemn, not to celebrate. Besides, the notion of "relaxation" in itself conflicted with the stilloperative work ethic: there was always the possibility of seriously misleading the viewer, suggesting that these people "played" entirely too much. So there are 


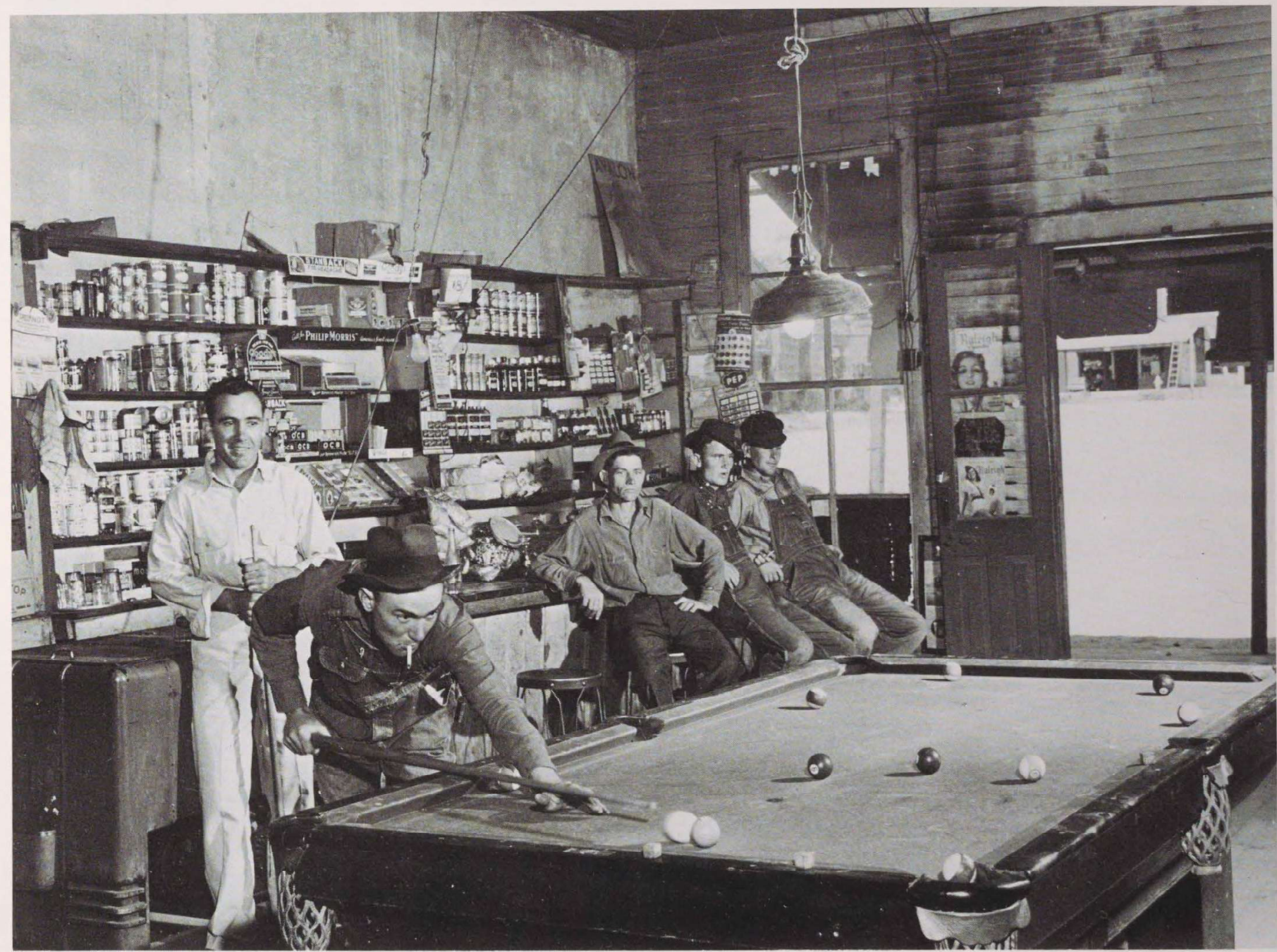

Figure 15 Jack Delano.

"Franklin, Heard County,

Georgia. Spring 1941. A

game of pool in the

general store." 44032-D. 


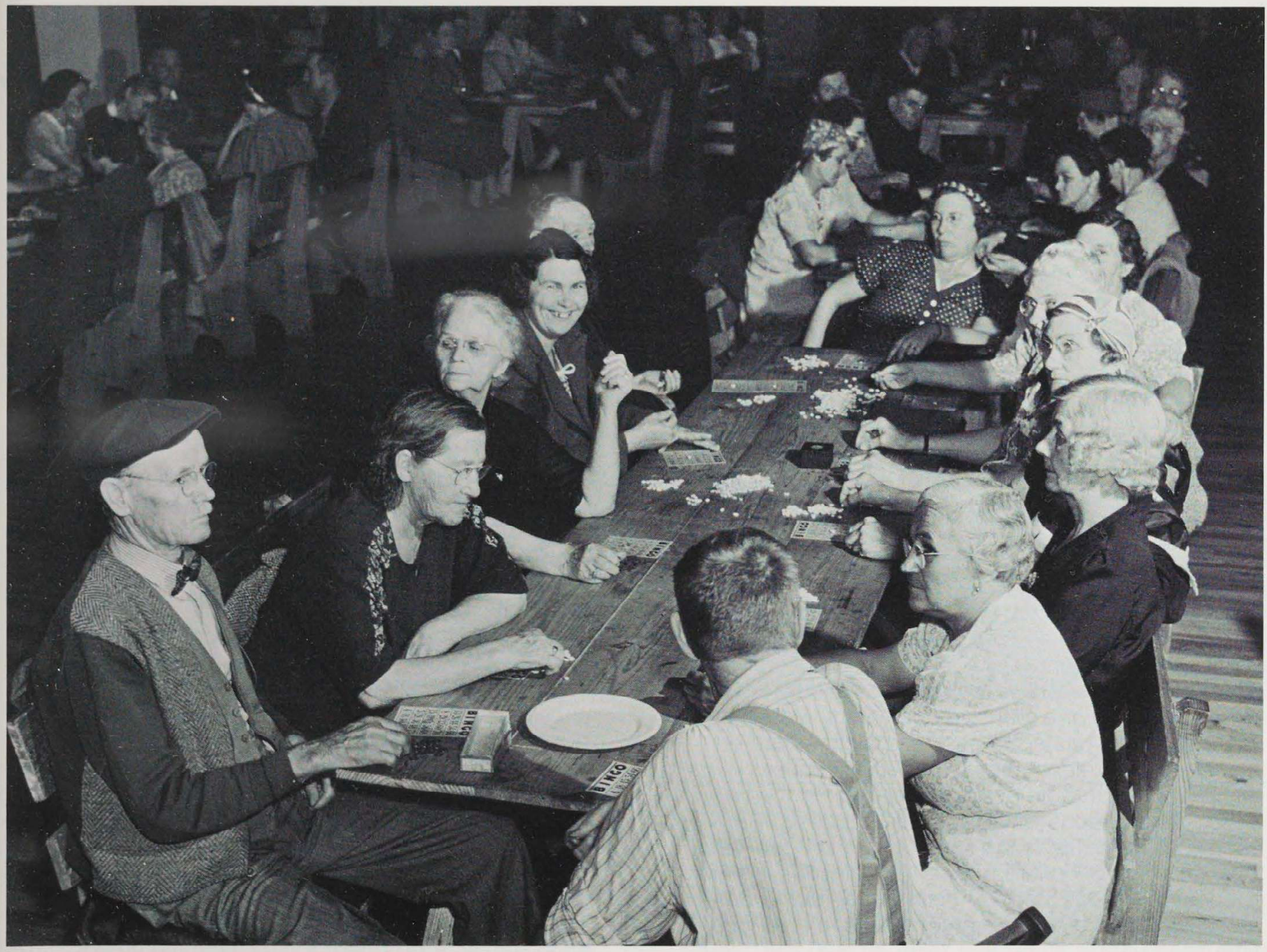

Figure 16 Marion Post

Wolcott. "Sarasota,

Florida. January 1941

Guests of a trailer

enjoying an evening of

'bingo'." 56947-D. 
few pictures, from any region, that fall into a category one would think deserved better in the 1930s, one which certainly gets more than its share of images today. At any rate, those pictures that do exist conform wonderfully to the subversive possibilities ever present in every art.

Stryker had wanted photographs of baseball and children playing (he didn't have many ideas on the subject; something like the film "Greased Lightning" was out of the question because most of the towns his photographers visited didn't have ten cars on a market day, let alone one you could put on a dirt track for ten laps), but the images that came back into the office in Washington were palpably congruent with the conditions of Southern reality encountered by FSA photographers: oppressive heat and grinding poverty. So it makes perfect sense that of all the activities, only two have any action - the baseball pitcher (Figure 17) and the horseshoe players (Figure 14), neither of whom is working up much of a sweat. Except for the most modest items, no activity includes either extensive or expensive equipment. Moreover, like the classic photographs, these pictures are neither candid nor spontaneous, but the openness of relationship exists to an even greater degree than posed photographs would suggest because, it seems, the majority of the subjects are in open collusion with the FSA photographer. This implies the existence of a shared motive: both photographer and subject want to give the appearance of a "real good time."

Every picture has its awkwardness or anomaly, as if to say that on this click, at least, the professional wasn't much in control. The white man with the strange look on his face (as he stares into the camera, wedged between two black dancers), in "Negro Juke Joint on a Saturday Evening" (Figure 8), shares something with the old gentleman "enjoying," the caption argues, "an evening of 'bingo,' " (Figure 16), but exactly what that is, beyond stark estrangement, will require the viewer to know much more about Clarksdale, Mississippi, in 1939, as well as what happens to old men who are outnumbered and surrounded at such events by old women, in places like Sarasota, Florida.
We know that the classic photographs reveal complex emotions, both in what they disclose and, to a greater extent, in what they invite. Their inner structure mediates strong feelings so that the viewer can sort out muted shades of anger or pain. These mundane pictures are emotionally more direct. They too contain an inner structure, but access to it is less a knowledge of formal aesthetics than it is a procedure involving complex "de-coding," dependent to a far greater extent than classic photographs upon caption, text, milieu, and a knowledge of how they were made. The expression of anger in a number of these pictures is illustrative. The two fans, locked outside the posh Duke football game, are more than merely uncomfortable in their tweed and mink attire (Figure 1); they seethe with a cold fury born of entitlement. The same intensity of emotion may be seen in the face of the judge at the Virginia horse show (Figure 11), clearly dissatisfied with the photographer's intrusion into this circle of privilege, and both the black migratory workers watching their fellow picker play checkers with a white man (white-shirted grower?) during what the caption regards as "slack season" (Figure 2) seem about as ready to break loose as the good ole boys watching that friendly game of pool, and decidedly not laughing, as is that smiling man with the cue (owner?), in Franklin, Heard County, Georgia (Figure 15).

As America edged into World War II, and then the war itself moved into higher and higher gear, federal agencies were dropped or conflated into others; programs and the ends they served changed radically. By the middle of 1942, Stryker was torn between staying in Washington and insuring the safety of the FSA collection ("The File") he had labored to shape, and which he knew was regarded ambivalently by those both in and out of power, and leaving an office where funding was always in doubt and yet where requests from places like the Office of War Information never ceased, wanting shots they could send overseas to show Our Boys and Our Allies the good life that had been left behind, how unified we all were at home now, fighting fascism together.

Instead, a little like the $\mathrm{ClO}$ and busy Walter Reuther, the FSA photographers had already, by the late 1930s, been searching out a more complex, less cheery perspective on the land. They roasted 100 percent Americans at play, like the White Plains Bridge Club, in Greene County, Georgia (Figure 9), the blandly identified "group of men" who were contentedly "playing backgammon outside a beach house" near Miami (Figure 18), and got a few regular fellas shooting craps ("during lunch hour," insists the caption) while building a war emergency pipeline from Texas to Illinois (Figure 10). One doubts that the American Rifle Association would have wanted to use 
Figure 17 Marion Post

Wolcott. "Shriever, Louisiana. Terrebonne, a Farm Security Administration project. A baseball game." 54345-D.

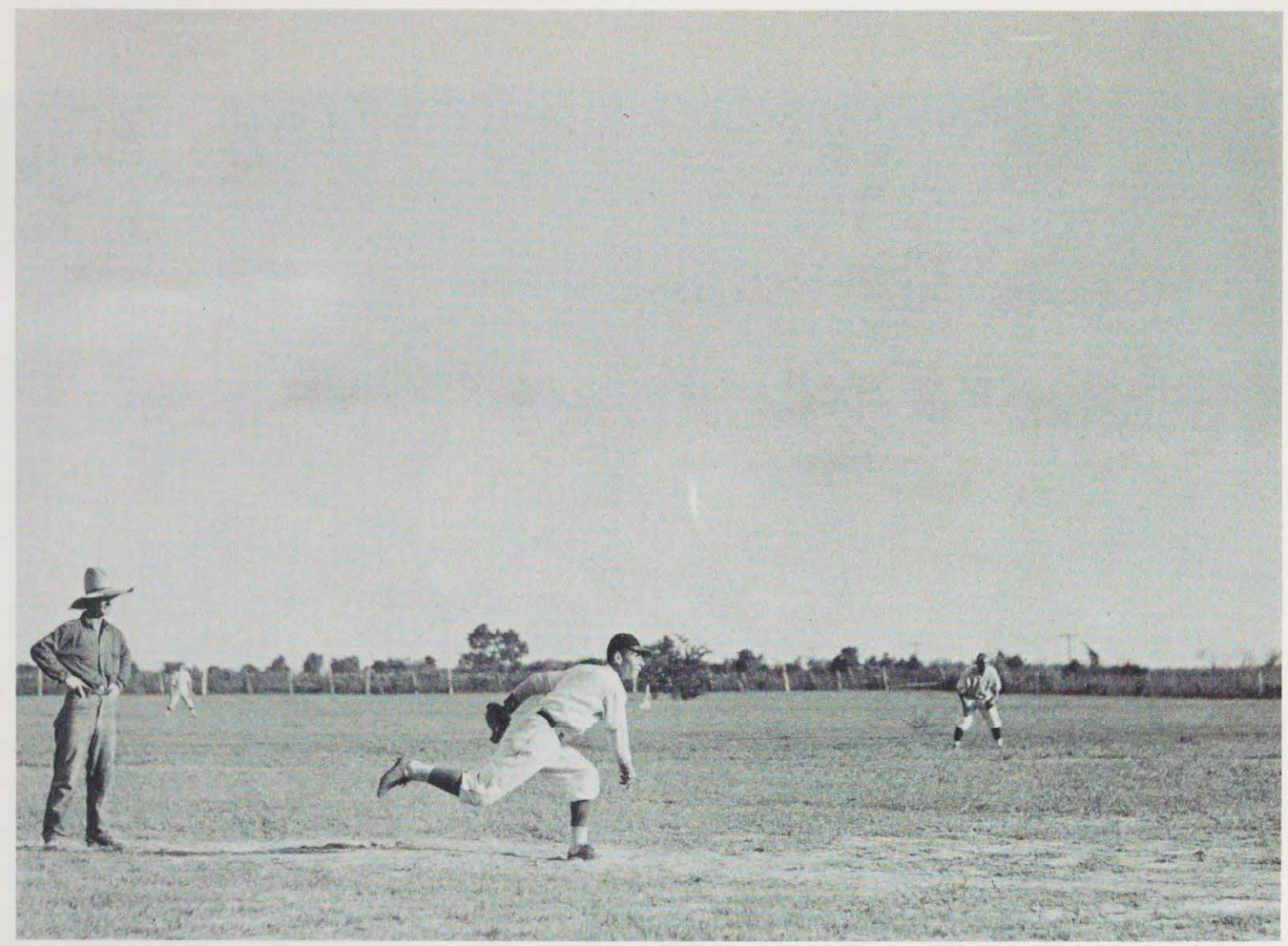

their shots of the black hunters and white hunters who are very posed (Figures 3 and 12) and who, in any event, would require rather special handling in an exhibition in order to avoid any "embarrassing" comparisons, though the price of Gordon Parks's trip to Daytona Beach must have been repaid, several times over, just hearing him recall what those laughing black basketball playing girls - in college, no lesswere like in 1943 (Figure 6). The caption for Mrs. J. L. Tuggle and her "nine-pound bass" which she caught "using catawba worm bait on a no. 10 hook" (Figure 13) leaves little to the imagination, or does it? And if that fellow in the rumpled baseball uniform, front row middle, at Irwinville Farms, Georgia (Figure 4), isn't stiff, he is doing an excellent job of "goofing" on the FSA photographer who is trying to form him up into a team picture.

Shahn was extremely gentle in handling his subjects. (His account of an auction in Central Ohio, actually a farm foreclosure, is the tenderest elegy in the FSA files.) But the dark lady dancing with three others at Cumberland Homestead, Tennessee (Figure 5), remains unassured, wary, does not give the impression she much trusts his purpose. The exact opposite is the case with Marion Post Wolcott's picture of those muskrat trappers (Figure 7), who appear to have been drinking cheap wine and having a damned good time since Prohibition began, and who are eager to have others join them. Indeed, if the viewer doesn't feel close enough to them to wonder about that giant, blank sky over the pitcher's mound in Shriever, Louisiana (Figure 17), and to wonder once again, just how far away that game is from those muskrat boys at Delacroix Island, St. Bernard Parish, the photographer has failed to make an essential connection: the very essence of vernacular pictures.

These glancing remarks, almost asides when one considers how much could and needs to be said about previously ignored background and technique, nevertheless begin to illustrate the manifold ironies and paradoxes, the latent energies, rich content, and unanswered questions even the slightest reading of vernacular pictures can yield. All of them are radically incomplete and, as a result almost wholly referential, and what they refer to is a region and a country that haven't yet begun to be explored. From a political point of view, they demonstrate the acceptance, in analysis, of the status quo and all the ideological implications of that position which necessarily follow. As art, they are another example of what happens to local or regional materials when they are inappropriately subjected to international "standards"; moreover, such neglect is an indication of the priorities that have dominated the American studies movement since its expansive, European excursions, in the late 1940 s and early 1950s. It is in an almost entirely 


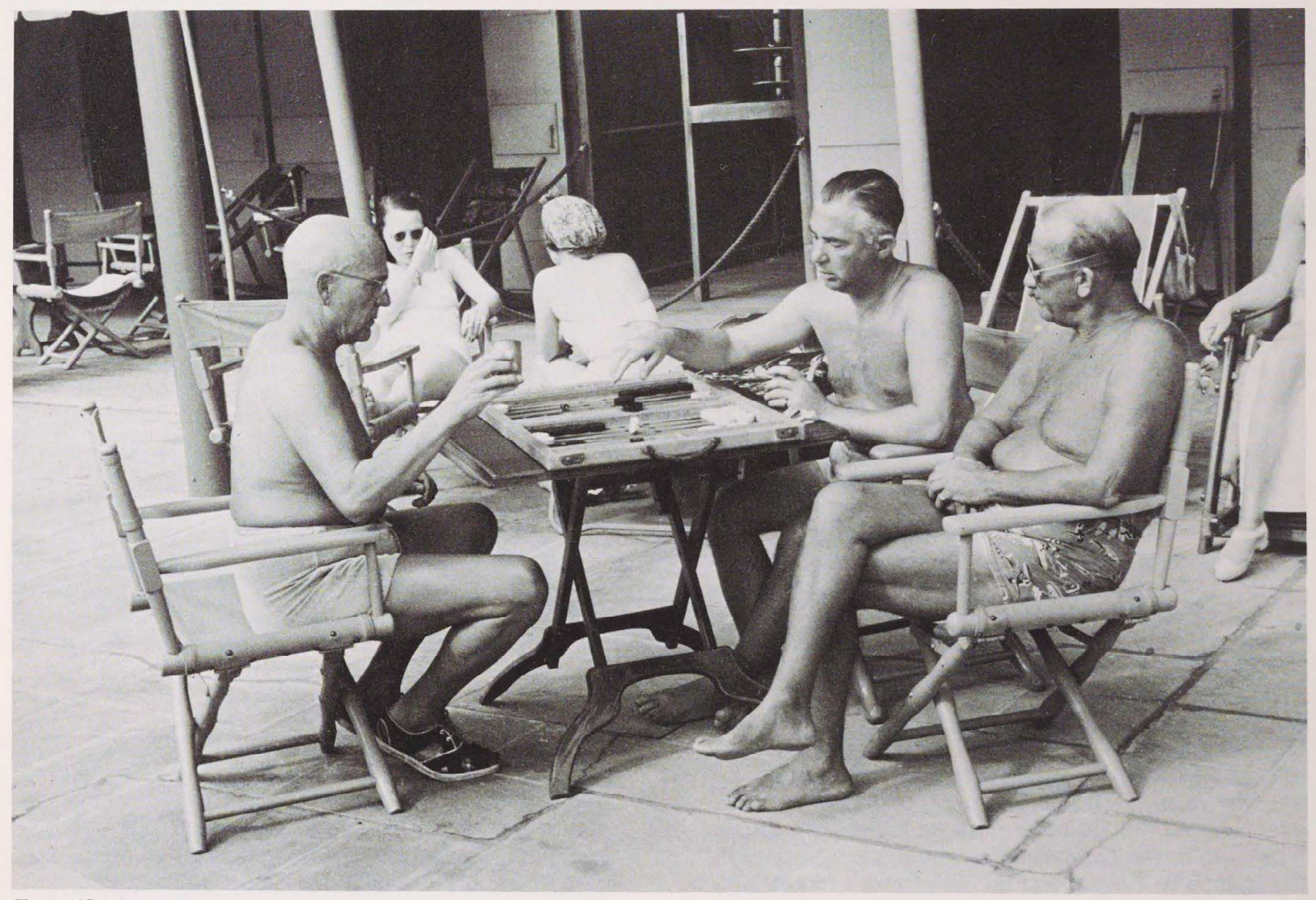

Figure 18 Marion Post

Wolcott. "Miami Beach,

Florida. January 1939. A

group of men playing

backgammon outside a

beach house." 30471-M2. 
overlooked area, however, that of the craft of photography, that perhaps the greatest mystification has occurred, and perhaps it is there that future reconsiderations of vernacular pictures in general and these FSA photographs in particular will have their origin.

For too long, photographers, historians, and critics of photography have attempted to put images into frames, as it were, as though they were taxonomists plopping bugs and butterflies into bottles, when the point has been not dissection and labeling - separation and isolation-but seeing the underlying unity and then telling others how all the pieces are connected. Shahn communicates some of what can happen to an artist, but for the ultimate benefit of us all, when these connections are made:

I remember the first place I went ... one of the resettlements FSA built. I found that as far as I was concerned, they were impossible to photograph. Neat little rows of houses. That wasn't my idea of something to photograph at all. But I had the good luck to ask someone, "Where are you all from? Where did they bring you from?" And when they told me I went on to a place called Scott's Run, and there it began. From there I went all through Kentucky, West Virginia, down to Arkansas, and Mississippi, Louisiana, in other words, I covered the mine country and the cotton country. I was terribly excited did no painting at all in that time. [Quoted in O'Neal 1976:46]

\section{Acknowledgments}

The main line of argument in this essay emerged from conversations over a period of many years with photographers H. Ramsey Fowler, Stu Cohen, and, especially, Christopher Seiberling. Others who have helped me are Robert Arruda, Charles Collins, F. Jack Hurley, Grace Seiberling, and Robert Coles, M.D. The argument has been greatly focused by work with my colleague, John D. Stoeckle, M.D., and it will appear in a joint work by us in another context, expanded and more detailed, in a book to be published by the MIT Press in 1983: Plain Pictures of Plain Doctoring: New Deal (FSA) Photographs of Doctors and Patients.

\section{Notes}

1 Vernacular as the common, everyday speech of ordinary people is a well-established category in literary analysis. There, learned, formalized patterns of speech or highly conscious, highly stylized modes of construction (as in the principles of classical rhetoric with its rigid insistence on the appropriate occasions for particular figures, tropes, and metaphors) are frequently contrasted with nonstandard expression that is native to a people or a region. Twentieth-century literature, like modern art, was energized by use of the vernacular, as in the writings of James Joyce and William Carlos Williams, and the rise of nineteenth-century English romanticism is regularly enough attributed to calls by the poets Wordsworth and Coleridge for a poetry whose language would be brought "near[er] to the real language of men." The most searching historical examination of the vernacular in literature is Eric Auerbach's Literary Language and Its Public in Late Latin Antiquity and in the Middle Ages (New York: Pantheon Books, 1978). Virtually any of Freud's seminal papers on psychoanalytic technique stress the centrality of common speech in psychotherapeutic transactions and the fact that something as common in constituent elements and form as the dream is nothing less than the "Roman road" to understanding the unconscious. And the history of Architecture is another field where the vernacular has been an important category encouraging the surge, most recently, of vernacular reconstructions in urban and rural, industrial and agricultural environments. Vernacular Architecture of the Lake Countries (London: Faber and Faber. 1974), for example, contains the following useful distinction by its author, R. W. Brunskill:

The building types included [in this work] are, of course, vernacular rather than "polite" in quality, and predominantly domestic and rural. They are "vernacular" - the products of local craftsmen meeting simple functional requirements according to traditional plans and procedures and with the aid of local building material and constructional methods, rather than "polite" - the efforts of professional designers, meeting the more elaborate needs of a formal way of life with the aid of internationally accepted rules and procedures, advanced constructional techniques, and materials chosen for aesthetic effect rather than local availability. [p. 15]

Introducing the vernacular as a category in the reading of photo graphs, however, raises special difficulties because not only is there mediation, but the central mediating device is nothing so simple as a typewriter transmitting words; it is a complex instrument known as a camera transmitting (?) images. Since the burden of this essay is, at least in part, to argue for ways in which this category might be introduced, a Note is scarcely the place to begin to unpack the result of dealing with cameras and images rather than with typewriters and words, though here it is worth noting that, with pictures, the vernacular may well be both intrinsic to the subject (intrinsic to the person, place, region) and part of a particular process - a certain manner of commissioning, making, and reproducing photographs. Just as it would be an error to assume that all snapshots - with their often stereotyped expectations, formats, executions, and responses - are vernacular, so it would be an error to accept the single frame as a vernacular picture rather than groups of pictures. Thus, the FSA's Roy Emerson Stryker was clearly on to something when he firmly instructed highly professional portraitists such as Russell Lee to "keep moving." Like the licensed, universitytrained architect sent "out" to work under local conditions with local materials, Stryker wrote to Lee in an extraordinary letter of January 1937: 
There are some outstandingly fine things among them [recent pictures Lee made]. In general, I have one criticism to make, namely, that perhaps you have not told as full a story as you might have. ... Would it not be better to have taken fewer families and spent more time with each?

Stryker went on, identifying further errors and outlining corrective techniques:

You have done many pictures of the families standing in front of their house or shack. They appear a bit stiff taken in this manner. These would be all right, provided we could show members of the same family in the house and doing various things. (Roy Emerson Stryker, Letter to Russell Lee, January 1937. Roy Stryker Collection, University of Louisville Photographic Archive, Louisville, Kentucky.)

2 For all the assembled information, this is in sum the reformist mes sage one finds in Documentary Expression and Thirties America (Stott 1973). Stott's examination of documentary is primarily an aesthetic one, uninformed by either a critical history or a critical politics. As a result, the book's moral judgments become the very strain of documentary they claim to discredit: manipulative moralizing. Leaving aside the argument that all documentary is by nature manipulative, it is as if the reader is made to "feel bad" about certain economic and social conditions in the absence of any solutions or, worse, any explanations. An impressive close analysis of Walker Evans's photographs, one which delineates the difference between Evans's intentions and those of his subjects (the ones we know from Let Us Now Praise Famous Men, 1941) redeems an otherwise misleading excursion through the genre.

3 It should go without saying that the following historical reconstruc tion is of the sort that can only take place at a very great distance, and only after information from countless sources has been carefully sifted, argued over, and resifted. Even then, it cannot be assumed that all parties will agree, not only on what happened or what did not happen, but what it meant that $X$ happened and $Y$ did not. Sadly, partisans of individual historical actors or institutions will routinely treat such analyses as nothing less than the imputation of "conspiratorial" motives toward their favorites, insisting that no one knew what was occurring, or that A did not know what was occurring, or that A did and it is the analysis which has misunderstood or distorted A. The necessity of the Russian Revolution is a good example of this category, and Lenin's role, as seen by Trotsky, a good example of this subsequent partisan inquiry.

4 Perhaps the most self-conscious, self-critical form of this can be found in Agee's text for Let Us Now Praise Famous Men. There. scattered about and typical, is the following: "When they saw the amount of equipment stowed in the back of our car, they showed that they felt they had been taken advantage of, but said nothing" (p. 25).

5 For each, the world of high-pressure, high-income image manufacture was nothing new: Evans's father had been an executive with Lord \& Thomas, a national advertising firm, based in Chicago. The son received art training at, in his words, "expensive private schools," and, after dropping out of Williams College, spent a year at the Sorbonne in 1926, which allowed him to view the School of Paris Painters, "a revolutionary eye education," as he would de scribe it years later. Lange's first marriage was to the painter and muralist Maynard Dixon, and she followed an apprenticeship in commercial portrait work in New York City with the establishment of a West Coast studio that, like her husband's murals, catered to San Francisco's well-off. Lee began as a chemical engineer and advanced to plant manager in Kansas City, where a first marriage to a painter and an inherited income from several of his grand-uncle's farms allowed him to move to "the world of West Coast art" in 1929 and then "an artists' colony" at Woodstock. N.Y., in 1931. There, like the others, he learned who bought what, and why.

6 The designation of kind is Christopher Seiberling's, though neither he nor the author is entirely satisfied with the actual word used to make the designation. A considerable debate has ranged among those who make pictures as to whether or not they are artists or photographers. As can be imagined, each term carries considerable freight. Until a more apt word comes along, the controversy is acknowledged but the word is kept because of its association with formal, aesthetic properties.

7 It is "Dust storm, Cimarron County, Oklahoma, 1936," in Rothstein (1978); "Dust storm, Cimarron County, Oklahoma, 1936. Arthur Rothstein," in Hurley's (1972); "Rothstein. Fleeing a dust storm; Cimarron County, Oklahoma, 1936," in Stryker-Wood (1973), and "Father and sons walking in the face of a dust storm, Cimarron County, Oklahoma, April 1936, Rothstein," in O'Neal (1976).

How the photographs received the captions they now bear is, however, another question. Historians of FSA photography have made suggestions but have not precisely sorted out either the process or the participants, and it may well be impossible at this point. But we do know that the photographers themselves had preferences, even demands. Meltzer (1978) has quoted the following account from Ron Partridge, Lange's driver/helper while she was photographing in the Imperial Valley, California, in 1937: "She would walk through the field and talk to people, asking simple questions - what are you picking? and they'd answer, tossing her whatever fruit or vegetable it might be. She'd show interest in their clothing, their knives, their bins, their trucks. How long have you been here? When do you eat lunch? ... Every hour or two she'd go sit in the car and write down verbatim what people had said" ( $p$. 19). Meltzer notes that certain captions Lange used would come directly from what she had heard.

In any case, we need neither the New Critics nor Walter Benjamin to suggest to us the ways in which captions alter our reading of the picture before us. That they are more important to the vernacular than the classic photographs is a point to be argued further along

8 Little wonder, then, that these are among the most emotionally satisfying photographs of the FSA photographers, or that the more explicit portraits are almost without exception uniformly extraordinary. Those by Lange - "Migratory laborer's wife near Childress, Texas, June 1938," "Woman of the Plains," "Ex-slave, Alabama, 1937"and Lee - "Negro crossing himself and praying over grave in cemetery. All Saints Day, New Rocks, Louisiana, October 1938." "Former sharecropper, New Madrid, Missouri, 1938"- are so superior as formal portraits as to cross the border into Evans's domain, discussed below.

9 Evans's notes, separated from his photographs in First and Last (1978), do not say where in Alabama. The nonreferential quality makes captions irrelevant, since the emotion generated routinely overwhelms the caption's intended specificity. This contradiction is especially harsh with someone like Lange, whose style was to get down "their exact words" and then to use them as an "extension" of the photograph. "Migrant Mother," for example, simply sweeps away the details as the composition of mother and child (children) whisks the viewer from California to Rome, to the Vatican's Pietà rather than Gallo's grapes.

10 Vernacular pictures should not be understood as somehow immune from the forces of ideology in a given culture that press upon the other modes; nor is their superior status, with respect to the other modes, a given. In the evaluation of literature, Leo Marx (1956) has written about Mark Twain's Huckleberry Finn that while the vernacular may be its distinctive feature, accounting for its success - in that particular novel - is another matter. "It means nothing," says 
Marx. "to contend that the novel is great because it is written in the native idiom unless, that is, we meant to impute some intrinsic or absolute value to the vernacular. That would be ridiculous." In the psychoanalytic tradition, however, a central aspect of treatment and an index of relative health - is the patient's ability to cut beneath successive layers of abstraction and to speak in their own language.

11 These are all defenses, and mobilized with good reason. Take a psychoanalyzed liberal like Lionel Trilling, who could write of Let Us Now Praise Famous Men in 1941: "[The one failure] . . is not a literary failure. ... it is a failure of moral realism. It lies in Agee's inability to see these people as anything but good. ... What creates this falsification is guilt ... despite Agee's clear consciousness of his guilt, he cannot control it," (1942:102). The operative word here is of course control and Trilling's concern was that intellectuals should explore their own privilege relative to others' oppression but not lose control while doing so. Whether Evans read Trilling or not, he certainly demonstrated his disregard when it came time for a second edition of the book. Realizing he had had his version of their lives, he added their vision - their posed presentations of self-the second time around.

\section{References}

- Agee, James

1941 Let Us Now Praise Famous Men. Boston: Houghton-Mifflin

- Coles, Robert

1972 The South Goes North: Vol. 3 of Children of Crisis. Boston: Atlantic-Little, Brown

- Evans, Walker

1978 Walker Evans: First and Last Photographs. New York: Harper \& Row

- Hurley, F. Jack

1972 Portrait of a Decade: Roy Stryker and the Development of Documentary Photography in the Thirties. Baton Rouge: Louisiana State University Press

1978 Russell Lee, Photographer. Dobbs Ferry, N.Y.: Morgan and Morgan.

- Marx, Leo

1956 The Pilot and the Passenger: Landscape Convention and the Style of Huckleberry Finn. American Literature xxvii (May). Reprinted in Mark Twain, A Collection of Critical Essays (Twentieth Century Views). Henry Nash Smith, ed. Englewood Cliffs, N.J.: Prentice-Hall, Inc. 1963, p. 48.

- Meltzer, Milton

1978 Dorothea Lange: A Photographer's Life. New York: Farrar, Straus and Giroux.

- O'Neal, Hank

1976 A Vision Shared: A Classic Portrait of America and Its People, 1935-1943. New York: St. Martin's Press.

- Pratt, Davis, ed.

1975 The Photographic Eye of Ben Shahn. Cambridge, Mass.: Harvard University Press.

- Rothstein, Arthur

1978 The Depression Years, As Photographed by Arthur Rothstein. New York: Dover.

- Sontag, Susan

1977 On Photography. New York: Farrar. Straus and Giroux.

- Stott, William

1973 Documentary Expression and Thirties America. New York: Oxford University Press.

- Stryker, Roy Emerson, and Nancy Wood

1973 In This Proud Land: America 1935-1943 as Seen in the FSA

- Trilling, Lionel Photographs. Boston: New York Graphic Society.

1942 Greatness with One Flaw in It. Kenyon Review iv(i).

- Welty, Eudora

1971 One Time, One Place. New York: Random House. 